\title{
Photochemical synthesis of ammonia and amino acids from nitrous oxide
}

Xiaofeng Zang ${ }^{1 *}$, Yuichiro Ueno ${ }^{1,2,3}$, Norio Kitadai ${ }^{2,3}$

${ }^{I}$ Department of Earth and Planetary Sciences, Tokyo Institute of Technology, 2-12-1 Ookayama, Meguro-ku, Tokyo 152-8551, Japan

${ }^{2}$ Earth-Life Science Institute (WPI-ELSI), Tokyo Institute of Technology, 2-12-1

Ookayama, Meguro-ku, Tokyo 152-8550, Japan

${ }^{3}$ Japan Agency for Marine-Earth Science and Technology (JAMSTEC), Natsushimacho, Yokosuka 237-0061, Japan

*Corresponding author:

Xiaofeng Zang

E-mail: zang.x.aa@m.titech.ac.jp

Tel: +818039340892

Key words:

Prebiotic synthesis, Nitrogen fixation, Origin of life, Nitrous oxide, Amino acids

This manuscript has been submitted for publication in Astrobiology. Please note that, despite having undergone peer-review, the manuscript has yet to be formally accepted for publication. Subsequent version of this manuscript may have slightly different content. If accepted, the final version of this manuscript will be available via the 'peer-reviewed DOI' link on the righthand side of this webpage. Please feel free to contact any of the authors; we welcome feedback. 


\begin{abstract}
Abiotic synthesis of ammonia and amino acids are important for origin of life and early evolution. Ammonia $\left(\mathrm{NH}_{3}\right)$ and organic nitrogen species may be possibly produced from nitrous oxide $\left(\mathrm{N}_{2} \mathrm{O}\right)$, which is a second abundant nitrogen species in the atmosphere. Here, we report a new photochemical experiment and evaluate whether $\mathrm{N}_{2} \mathrm{O}$ can be used as a nitrogen source for prebiotic synthesis in the atmosphere. We conducted a series of experiments using a gas mixture of $\mathrm{N}_{2} \mathrm{O}+\mathrm{CO}, \mathrm{N}_{2} \mathrm{O}+\mathrm{CO}_{2}$ or $\mathrm{N}_{2} \mathrm{O}+\mathrm{H}_{2}$ with the presence of liquid water. The results demonstrated that $\mathrm{NH}_{3}$, methyl amine $\left(\mathrm{CH}_{3} \mathrm{NH}_{2}\right)$ and some amino acids such as glycine, alanine and serine can be synthesized through photochemistry from $\mathrm{N}_{2} \mathrm{O}$ even without metal catalysts. $\mathrm{NH}_{3}$ can be produced not only from $\mathrm{CO}+\mathrm{N}_{2} \mathrm{O}$, but also from $\mathrm{H}_{2}+\mathrm{N}_{2} \mathrm{O}$. Glycine can be synthesized from $\mathrm{CH}_{3} \mathrm{NH}_{2}$ and $\mathrm{CO}_{2}$, which can be produced from $\mathrm{N}_{2} \mathrm{O}$ and $\mathrm{CO}$ under $\mathrm{UV}$ irradiation. Our work demonstrated for the first time that $\mathrm{N}_{2} \mathrm{O}$ could be an important nitrogen source and provide a new process for synthesizing ammonia and organic nitrogen species that was not considered previously. Contribution of organic synthesis from $\mathrm{N}_{2} \mathrm{O}$ should therefore be considered when discussing the prebiotic chemistry on primitive Earth.
\end{abstract}




\section{Introduction}

Nitrogen is an essential element for the origin of life and its evolution. The famous Miller-Urey experiment demonstrated that key building blocks of life, such as amino acids, can be synthesized from a reducing atmosphere including $\mathrm{NH}_{3}, \mathrm{CH}_{4}, \mathrm{H}_{2}$ and $\mathrm{H}_{2} \mathrm{O}$ (Miller 1953, 1955; Miller and Urey 1959). However, as is widely accepted nowadays, primitive atmosphere was less reducing, containing carbon source as mostly $\mathrm{CO}_{2}$ and nitrogen source as mostly $\mathrm{N}_{2}$ (e.g., Walker 1977, 1985; Kasting 1993). It is far less efficient to synthesize organic nitrogen compounds from the $\mathrm{N}_{2}$ dominate atmosphere (Schlesinger and Miller, 1983). Therefore, it is crucial to understand how $\mathrm{NH}_{3}$ and organic nitrogen molecules can be produced from atmosphere when discussing the origin of life.

Abiotic ammonia formation has been discussed by both experimental and theoretical studies: reduction of $\mathrm{NO}_{2}^{-}$and $\mathrm{NO}_{3}{ }^{-}$by aqueous iron (II) $\mathrm{Fe}^{2+}$ (Summers and Chang, 1993) or by ferrous sulfide FeS under acidic conditions (Summers 2005), directly reduction of NO by FeS (Summers et al., 2012); released by decomposition of ammonium micas (Eugster 1966); reduction of $\mathrm{N}_{2} / \mathrm{NO}_{2}{ }^{-} / \mathrm{NO}_{3}{ }^{-}$in typical hydrothermal systems by minerals catalysts (Brander et al., 1998, 2008; Schoonen and Xu 2001; Smirnov et al., 2008; Singireddy et al., 2012). These studies focus on $\mathrm{NO}_{\mathrm{x}}$ as an intermediate nitrogen species to synthesize ammonia, which can be produced from atmosphere $\mathrm{N}_{2}$ by lightning and or meteorite impact (Yung and Mcelroy, 1979; Chyba and Sagan, 1991; Nna Mvondo et al., 2005; Laneuville et al., 2018). On the other hand, nitrous oxide $\left(\mathrm{N}_{2} \mathrm{O}\right)$ may also be alternative intermediate for ammonia formation, but has not been explored yet.

Prebiotic $\mathrm{N}_{2} \mathrm{O}$ level in early atmosphere is largely uncertain, though Airapetian et al. (2016) suggested that $\mathrm{N}_{2} \mathrm{O}$ could be efficiently produced ( $20 \sim 3000 \mathrm{ppbv}$ ) owing to high activity of young Sun. Nna Mvondo et al. $(2001,2005)$ demonstrated that $\mathrm{N}_{2} \mathrm{O}$ can be produced abiotically by coronal discharge in $\mathrm{N}_{2}-\mathrm{CO}_{2}$ gas mixtures. It is noticed that $\mathrm{N}_{2} \mathrm{O}$ is also produced by spark discharge of $\mathrm{N}_{2}-\mathrm{CO}_{2}$ atmosphere and subsequent photochemical process (Summers and Khare 2007), though the experiment of Summers and Khare (2007) did not analyze $\mathrm{NH}_{3}$ and other products during the experiment. It is possible that $\mathrm{N}_{2} \mathrm{O}$ could be a nitrogen source to synthesize $\mathrm{NH}_{3} / \mathrm{NO}_{2}{ }^{-} / \mathrm{NO}_{3}{ }^{-}$or other organic nitrogen species. However, there are no experimental studies where $\mathrm{N}_{2} \mathrm{O}$ is the initial nitrogen source.

Abiotic source of amino acids by various kinds of energy source has been studied for long years. They include spark discharges (Miller 1953, 1955; Miller and Urey 1959), 
irradiation by ultraviolet lights, comic rays and/or solar flare particles (Groth and Weyssenhoff 1960; Sagan and Khare 1971; Kobayashi et al., 1989; 1990; 1998; 1999; Takahashi et al., 1999; Utsumi and Thkahashi 1998), hydrothermal synthesis (Oro et al., 1959; Lowe et al., 1963) and shock heating by meteorite impacts (Bar-Nun et al., 1970). Previous studies of atmospheric UV synthesis of amino acids used hydrocarbon $\left(\mathrm{CH}_{4}\right.$ or $\mathrm{C}_{2} \mathrm{H}_{6}$ ) and $\mathrm{NH}_{3}$ as starting materials, and have demonstrated the production of glycine, alanine and serine (Groth and Weyssenhoff 1960; Sagan and Khare 1971), though it is uncertain whether amino acid can be produced from $\mathrm{N}_{2} \mathrm{O}$.

Here, we report a new photochemical experiment and evaluate whether $\mathrm{N}_{2} \mathrm{O}$ can be used as a nitrogen source to produce $\mathrm{NH}_{3}$ and other organic nitrogen species. We conducted a series of experiments using a gas mixture of $\mathrm{N}_{2} \mathrm{O} / \mathrm{CO}$ or $\mathrm{N}_{2} \mathrm{O} / \mathrm{CO}_{2}$ or $\mathrm{N}_{2} \mathrm{O} / \mathrm{H}_{2}$ with the presence of liquid water under the irradiation of ultraviolet light. The results indicated that $\mathrm{NH}_{3}$ and some amino acids can be synthesized through photochemistry from $\mathrm{N}_{2} \mathrm{O}$ even without metal catalysts.

\section{Materials and Methods}

\subsection{Photochemical experiment}

Outline of experimental apparatus are illustrated in Figure 1. Experiments were conducted in a glass flask $(457 \mathrm{~mL})$ with two ports, one is connected to the vacuum line for introduction and extraction of gas sample, and the other is for injection of $\mathrm{N}_{2} \mathrm{O}$ or $\mathrm{N}_{2}$. The top of the flask is made of UV-grade synthetic quartz window, which is transparent for $>175 \mathrm{~nm}$ photon.

Before the UV irradiation, $50 \mathrm{~mL}$ of doubly-distilled water was injected and frozen by liquid nitrogen for degassing impurity. After the freeze-pump-thaw cycle twice, $\mathrm{CO}$ or $\mathrm{CO}_{2}$ was introduced into the flask from the vacuum line at $25^{\circ} \mathrm{C}$ and then $10 \mathrm{ccSTP}$ of $\mathrm{N}_{2} \mathrm{O}$ or $\mathrm{N}_{2}$ gas was injected into the flask using a gas-tight syringe. After introducing the gas mixture, the flask was kept at $25^{\circ} \mathrm{C}$ using a water bath (MC-1, ASONE). An aliquot of gas phase $(407 \mathrm{cc})$ was sampled from the vacuum line for measuring gas concentration before the UV irradiation (Oh).

A high-pressure xenon arc lamp (Xe lamp: Cermax, CX-04E, output setting $20 \mathrm{~A}$ ) is used for the UV source, which has solar-like UV spectrum (Figure 2). In the experiment (A), UV light was irradiated vertically from the top to the surface of liquid water, while in the experiment (B), the flask was horizontally placed with $20 \mathrm{~mL}$ water and UV light 
was irradiated only into the gas phase. Experiment-1B was conducted to figure out whether $\mathrm{NH}_{4}{ }^{+}$and amino acids were produced from reactions in gas phase or in aqueous phase. During the irradiation, water temperature typically increasing up to $40^{\circ} \mathrm{C}$.

After the irradiation $(1 \mathrm{~h}, 3 \mathrm{~h}, 5 \mathrm{~h}, 8 \mathrm{~h}$, or $12.5 \mathrm{~h})$, the flask was cooled and kept at $25^{\circ} \mathrm{C}$, and then gas sample was collected from the vacuum line using a stainless steel finger $(1.16 \mathrm{~mL})$. After the collection of gas sample, remaining liquid in the flask was fully collected after each experiment.

\subsection{Quantitative analysis of gas phase}

Gas samples were analyzed by gas chromatograph (GC-4000, GL Sciences) equipped with two detectors; pulsed discharge detector (PDD) and thermal conductivity detector (TCD). The GC housed an initial $2 \mathrm{~m}$ column packed with SHINCARBON-ST (2.2 mm I.D.) and a second $2 \mathrm{~m}$ Hayesep Q column (2.2 $\mathrm{mm}$ I.D.). Pure helium gas is used as the carrier gas.

Speciation and concentrations in the gas sample were determined by the retention time and peak area compared with known amount of standard gas, including pure $\mathrm{CO}$, $\mathrm{CO}_{2}, \mathrm{H}_{2}$ and $\mathrm{N}_{2} \mathrm{O}$ gas ( $>99.5 \%$, GL Sciences) and mixed standard gas $\left(\mathrm{N}_{2} 93.954 \%, \mathrm{CH}_{4}\right.$ $0.996 \%, \mathrm{C}_{2} \mathrm{H}_{6} 1.01 \%, \mathrm{n}-\mathrm{C}_{3} \mathrm{H}_{8} 1.01 \%, \mathrm{i}-\mathrm{C}_{3} \mathrm{H}_{8} 1.01 \%, \mathrm{CO}_{2} 1.01 \%$, GL Sciences).

\subsection{Quantitative analysis of dissolved species}

Products dissolved in liquid sample were analyzed by high performance liquid chromatography (HPLC, Shimadzu) equipped with 4 different columns:

Organic acids were measured by the HPLC system equipped with an electric conductivity detector and an anion exchange column (Shin-pack SCR-102H, Shimadzu) at $40^{\circ} \mathrm{C}$. The p-Toluene sulfonic acids aqueous solution $(5 \mathrm{mM})$ was used as the eluent at a rate of $1.6 \mathrm{ml} \mathrm{min}^{-1}$.

Inorganic anion was measured by the HPLC system equipped with a suppressed conductivity detector and an anion exchange column (IC SI-90 4E, Shodex) at $40^{\circ} \mathrm{C}$. A mixture of $1.8 \mathrm{mM} \mathrm{Na}_{2} \mathrm{CO}_{3}$ and $1.7 \mathrm{mM} \mathrm{NaHCO}_{3}$ aqueous solution was used as the

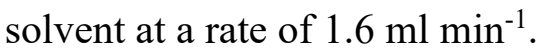

Ammonia was measured by the HPLC system equipped with an electric conductivity detector and an anion exchange column (Shin-pack IC-C4, Shimadzu) at $40^{\circ} \mathrm{C}$. The oxalic

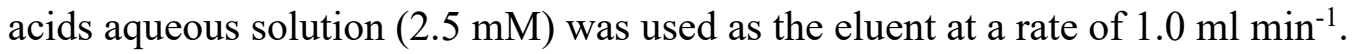


Amino acids were quantified by another HPLC system (JASCO) equipped with a fluorescence detector and an ion exchange column (AApak Na II-S2, JASCO) at $40^{\circ} \mathrm{C}$.

For determining retention time and calibration curve, we used following standard reagents: mixed aqueous solutions containing sodium formate $\mathrm{HCOONa}(98.0 \%$, Wako), sodium acetate $\mathrm{CH}_{3} \mathrm{COONa} \cdot 3 \mathrm{H}_{2} \mathrm{O}\left(99.0 \%\right.$, Wako), glycolic acid $\mathrm{C}_{2} \mathrm{H}_{4} \mathrm{O}_{3}(99 \%$, SigmaAldrich) and glyoxylic acid monohydrate $\mathrm{C}_{2} \mathrm{H}_{2} \mathrm{O}_{3} \cdot \mathrm{H}_{2} \mathrm{O}(98.0 \%$, Sigma-Aldrich), sodium nitrite $\mathrm{NaNO}_{2}$ (98.5\%, Wako), sodium nitrate $\mathrm{NaNO}_{3}$ (99.0\%, Wako), ammonium chloride $\mathrm{NH}_{4} \mathrm{Cl}$ (99.5\%, Wako), glycine $\mathrm{H}_{2} \mathrm{NCH}_{2} \mathrm{COOH}$ (PEPTIDE INSTITUTE), $\beta$ alanine (PEPTIDE INSTITUTE), and serine (PEPTIDE INSTITUTE).

\section{Results}

Results of all experiments are showed in Table 1.

\subsection{Experiment of $\mathrm{N}_{2} \mathrm{O}+\mathrm{CO}+\mathrm{H}_{2} \mathrm{O}(\mathrm{A})$}

In gas phase, both $\mathrm{N}_{2} \mathrm{O}$ and $\mathrm{CO}$ were consumed, while $\mathrm{H}_{2}, \mathrm{~N}_{2}, \mathrm{CO}_{2}$ were formed as major products, and $\mathrm{CH}_{4}$ was determined after 5 hours' irradiation. Meanwhile, $\mathrm{O}_{2}$ was below the detection limit. In aqueous phase, organic acids such as formic acid $\mathrm{HCOOH}$, acetic acid $\mathrm{CH}_{3} \mathrm{COOH}$, glycolic acid $\mathrm{CH}_{2}(\mathrm{OH}) \mathrm{COOH}$ and glyoxylic acid $\mathrm{CHOCOOH}$ were produced. And $\mathrm{NH}_{4}{ }^{+}$, methylamine as well as amino acids such as glycine, $\beta$ alanine and serine were determined. $\mathrm{NO}_{2}{ }^{-}$and $\mathrm{NO}_{3}{ }^{-}$were below the detection limit. Chromatogram of amino acids can be seen in Appendix.

For organic acids, formic acid was main product with $3.1 \%$ yield against the starting CO. The $\mathrm{NH}_{4}{ }^{+}$yield against initial $\mathrm{N}_{2} \mathrm{O}$ was about $2.3 \%$ and glycine yield was about $0.05 \%$ $(0.05 \%$ against initial $\mathrm{CO})$, respectively. The yields of each species based on initial CO or initial $\mathrm{N}_{2} \mathrm{O}$ as a function of irradiation time are showed in Figure 3.

\subsection{Experiment of $\mathrm{N}_{2} \mathrm{O}+\mathrm{CO}+\mathrm{H}_{2} \mathrm{O}$ (B)}

Product species in gas phase were similar to those in experiment (A) except $\beta$-alanine, which was below the detection limit in experiment (B). The yields of each species against initial $\mathrm{CO}$ or initial $\mathrm{N}_{2} \mathrm{O}$ as a function of irradiation time are showed in Figure 3 as well. Compared with experiment (A), yields of formic acid and $\mathrm{NH}_{4}{ }^{+}$were of the same digit, while yields of acetate acid, glycine and serine were only $1 / 10$ of those in experiment $A$.

\subsection{Experiment of $\mathrm{N}_{2} \mathrm{O}+\mathrm{H}_{2} \mathrm{O}$}


When $\mathrm{CO}$ was not included in initial gas mixture, $\mathrm{N}_{2}$ and $\mathrm{O}_{2}$ were produced in gas phase when $\mathrm{N}_{2} \mathrm{O}$ was consumed. On the other hand, $\mathrm{NH}_{4}^{+}$was below the detection limit in aqueous phase, instead oxidizing species such as $\mathrm{NO}_{2}{ }^{-}$and $\mathrm{NO}_{3}{ }^{-}$were produced. This indicated that $\mathrm{NH}_{4}{ }^{+}$cannot be produced simply through photolysis of $\mathrm{N}_{2} \mathrm{O}$ and $\mathrm{H}_{2} \mathrm{O}$ and that $\mathrm{CO}$ contribute to the formation of $\mathrm{NH}_{3}$ in experiment $\mathrm{N}_{2} \mathrm{O}+\mathrm{CO}+\mathrm{H}_{2} \mathrm{O}$.

\subsection{Experiment of $\mathrm{N}_{2}+\mathrm{CO}+\mathrm{H}_{2} \mathrm{O}$}

When nitrogen source was changed to $\mathrm{N}_{2}$, no N-bearing species other than $\mathrm{N}_{2}$ were detected in gas phase or aqueous phase. Meanwhile, $\mathrm{CO}_{2}, \mathrm{H}_{2}$, and $\mathrm{CH}_{4}$ were produced in gas phase, and the same kinds of organic acids detected in experiment of $\mathrm{N}_{2} \mathrm{O}+\mathrm{CO}+\mathrm{H}_{2} \mathrm{O}$ were produced in aqueous phase. These organic molecules were considered to be produced from photolysis of $\mathrm{CO}$ and $\mathrm{H}_{2} \mathrm{O}$.

\subsection{Experiment of $\mathrm{N}_{2} \mathrm{O}+\mathrm{CO}_{2}+\mathrm{H}_{2} \mathrm{O}$}

When carbon source was changed to less reducing gas like $\mathrm{CO}_{2}$, which is thought to be the main composition of primitive atmosphere of Earth and Mars, only $\mathrm{N}_{2}$ and $\mathrm{O}_{2}$ were produced in gas phase while $\mathrm{N}_{2} \mathrm{O}$ was consumed, no other $\mathrm{N}$-bearing species or organic acids were detected. This experiment once again indicated that prebiotic chemistry favors reducing atmosphere than neutral or oxidizing atmosphere.

\subsection{Experiment of $\mathrm{N}_{2}+\mathrm{CO}_{2}+\mathrm{H}_{2} \mathrm{O}$}

Gas mixture in this experiment is widely considered to be the main composition of primitive atmosphere. But no N-bearing species or organic molecules were detected.

\section{Discussion}

\subsection{Production of main gas species}

In our experiment, $\mathrm{CO}_{2}$ and $\mathrm{N}_{2}$ were the two most abundant species produced from $\mathrm{CO}$ and $\mathrm{N}_{2} \mathrm{O}$ under the presence of water. The $\mathrm{CO}_{2}$ is formed mainly through the following reactions (Calvert and Pitts, 1966; DeMore et al., 1992):

$$
\begin{aligned}
& \mathrm{H}_{2} \mathrm{O}+h v(<180 \mathrm{~nm}) \rightarrow \mathrm{H}+\mathrm{OH} \\
& \mathrm{CO}+\mathrm{OH} \rightarrow \mathrm{CO}_{2}+\mathrm{H}
\end{aligned}
$$

On the other hand, $\mathrm{N}_{2}$ are formed from the photolysis of $\mathrm{N}_{2} \mathrm{O}$ through the following 
reactions (Preston and Barr, 1971; Schmidt et al., 2011):

$$
\mathrm{N}_{2} \mathrm{O}+h v(<250 \mathrm{~nm}) \rightarrow \mathrm{N}_{2}+\mathrm{O}\left({ }^{1} \mathrm{D}\right)
$$

It is known that the $\mathrm{N}_{2} \mathrm{O}$ is further reacted with $\mathrm{O}\left({ }^{1} \mathrm{D}\right)$ to form $\mathrm{NO}$ (Prakash et al., 2005) :

$$
\begin{aligned}
\mathrm{N}_{2} \mathrm{O}+\mathrm{O}\left({ }^{1} \mathrm{D}\right) & \rightarrow \mathrm{N}_{2}+\mathrm{O}_{2} \\
& \rightarrow \mathrm{NO}+\mathrm{NO}
\end{aligned}
$$

Photolysis rates of $\mathrm{H}_{2} \mathrm{O}$ and $\mathrm{N}_{2} \mathrm{O}$ can be estimated from production rates of $\mathrm{CO}_{2}$ and $\mathrm{N}_{2}$, respectively, using the reactions R1-R4. The production of NO could initiate the chain reactions to form $\mathrm{HNO}_{2}, \mathrm{HNO}_{3}, \mathrm{NH}_{3}$ and organic nitrogen compounds.

\subsection{Synthesis of $\mathrm{C} 1$ compounds}

In our study, amino acids may have been produced from organic acids or aldehydes. It is important to understand the key reactions to form $\mathrm{C}-\mathrm{H}-\mathrm{O}$ species as an amino acid precursor. When $\mathrm{CO}$ is the only carbon source, the reaction between $\mathrm{CO}$ and $\mathrm{H}$ radicals should initiate organic synthesis, which produce formyl radical (HCO) and then formaldehyde ( $\mathrm{HCHO}$ ) through the following reactions (Hikida et al., 1971; Ahumada et al., 1972; Bar-Nun and Chang 1983; Hochanadel et al., 1980; Pavlov et al., 2001):

$$
\begin{aligned}
& \mathrm{CO}+\mathrm{H}+\mathrm{M} \rightarrow \mathrm{HCO}+\mathrm{M} \\
& \mathrm{HCO}+\mathrm{HCO} \rightarrow \mathrm{HCHO}+\mathrm{CO}
\end{aligned}
$$

where $\mathrm{M}$ represents any third body collision partner. Once the $\mathrm{HCO}$ and $\mathrm{HCHO}$ formed, radical chain reactions can produce a number of organic carbon species.

In the gas phase, formic acid $(\mathrm{HCOOH})$ could be produced by oxidation of formaldehyde (Yetter et al., 1989):

$$
\mathrm{HCHO}+\mathrm{OH} \rightarrow \mathrm{HCOOH}+\mathrm{H}
$$

The formaldehyde also reacts with $\mathrm{H}$ and produce molecular hydrogen $\left(\mathrm{H}_{2}\right)$, methoxy radical $\left(\mathrm{CH}_{3} \mathrm{O}\right)$, methanol $\left(\mathrm{CH}_{3} \mathrm{OH}\right)$, methyl radical $\left(\mathrm{CH}_{3}\right)$ and methane $\left(\mathrm{CH}_{4}\right)($ Baulch et al., 1992, 1994; Yung et al., 1988):

$$
\begin{aligned}
& \mathrm{HCHO}+\mathrm{H} \rightarrow \mathrm{H}_{2}+\mathrm{HCO} \\
& \mathrm{HCHO}+\mathrm{H}+\mathrm{M} \rightarrow \mathrm{CH}_{3} \mathrm{O}+\mathrm{M} \\
& \mathrm{CH}_{3} \mathrm{O}+\mathrm{H}_{2} \rightarrow \mathrm{CH}_{3} \mathrm{OH}+\mathrm{H} \\
& \mathrm{CH}_{3} \mathrm{OH}+h v(160-200 \mathrm{~nm}) \rightarrow \mathrm{HCHO}+\mathrm{H}_{2} \\
& \rightarrow \mathrm{CH}_{3} \mathrm{O}+\mathrm{H} \\
& \rightarrow \mathrm{CH}_{3}+\mathrm{OH} \\
& \rightarrow \mathrm{CH}_{2} \mathrm{OH}+\mathrm{H}
\end{aligned}
$$




$$
\mathrm{CH}_{3}+\mathrm{H}_{2} \rightarrow \mathrm{CH}_{4}+\mathrm{H}
$$

The $\mathrm{CH}_{4}$ reacts back into $\mathrm{CH}_{3} \mathrm{OH}$ and $\mathrm{CH}_{3}$ in our system:

$$
\mathrm{CH}_{4}+\mathrm{CH}_{3} \mathrm{O} \rightarrow \mathrm{CH}_{3} \mathrm{OH}+\mathrm{CH}_{3}
$$

Although the $\mathrm{CH}_{3} \mathrm{OH}$ was not measured in our experiment, $\mathrm{CH}_{4}$ is likely produced from the above mechanism.

\subsection{Synthesis of $\mathrm{C} 2$ compounds}

It is hard to determine the exact photochemical mechanism to form various $\mathrm{C} 2$ compounds, though following reactions are possible to make C-C-bounding:

$$
\begin{aligned}
& \mathrm{CH}_{3}+\mathrm{HCO}+\mathrm{M} \rightarrow \mathrm{CH}_{3} \mathrm{CHO}+\mathrm{M} \\
& \mathrm{HCO}+\mathrm{HCO}+\mathrm{M} \rightarrow(\mathrm{CHO})_{2}+\mathrm{M}
\end{aligned}
$$

where $\mathrm{CH}_{3} \mathrm{CHO}$ and $(\mathrm{CHO})_{2}$ represents acetaldehyde and glyoxal, respectively. Similar to the oxidation of formaldehyde ( $\mathrm{R} 7)$, acetic acid $\left(\mathrm{CH}_{3} \mathrm{COOH}\right)$ can also be produced by oxidation of acetaldehyde:

$$
\mathrm{CH}_{3} \mathrm{CHO}+\mathrm{OH} \rightarrow \mathrm{CH}_{3} \mathrm{COOH}+\mathrm{H}
$$

Similarly, glyoxylic acid $(\mathrm{CHOCOOH})$ can be formed by the same $\mathrm{OH}$ oxidation process from glyoxal $(\mathrm{CHO})_{2}$ :

$$
\mathrm{CHOCHO}+\mathrm{OH} \rightarrow \mathrm{CHOCOOH}+\mathrm{H}
$$

Also, glycolic acid $\left(\mathrm{HOCH}_{2} \mathrm{COOH}\right)$ could be synthesized from $\mathrm{OH}$ oxidation of glycolaldehyde $\left(\mathrm{HOCH}_{2} \mathrm{CHO}\right)$, which could generate from $\mathrm{CH}_{2} \mathrm{OH}$ radicals (R11d) combining with $\mathrm{HCHO}$, as pointed out in Nuevo et al. (2010):

$$
\begin{aligned}
& \mathrm{CH}_{2} \mathrm{OH}+\mathrm{HCHO} \rightarrow \mathrm{HOCH}_{2} \mathrm{CHO}+\mathrm{H} \\
& \mathrm{HOCH}{ }_{2} \mathrm{CHO}+\mathrm{OH} \rightarrow \mathrm{HOCH}_{2} \mathrm{COOH}+\mathrm{H}
\end{aligned}
$$

\subsection{Formation of $\mathrm{HNO}_{2}$ and $\mathrm{HNO}_{3}$ from $\mathrm{N}_{2} \mathrm{O}$ under oxidizing condition}

In an oxidizing O-H-N system like $\mathrm{N}_{2} \mathrm{O}+\mathrm{H}_{2} \mathrm{O}$, main N-bearing products were $\mathrm{HNO}_{2}$ and $\mathrm{HNO}_{3}$. Both are considered to be synthesized via a key intermediate $\mathrm{HNO}$ in the gas phase or potentially in aqueous phase (Summers and Khare, 2007). Gas phase reaction pathway is considered to start from NO that generated from [R4b], it could combine with $\mathrm{H}$ radicals to form $\mathrm{HNO}$ :

$$
\mathrm{NO}+\mathrm{H}+\mathrm{M} \rightarrow \mathrm{HNO}+\mathrm{M}
$$

The HNO also reacts with $\mathrm{H}$ radicals to generate NO radicals so that $\mathrm{NO}$ can be supplied sustainably in the system: 


$$
\mathrm{HNO}+\mathrm{H} \rightarrow \mathrm{NO}+\mathrm{H}_{2}
$$

Meanwhile, $\mathrm{N}_{2} \mathrm{O}$ itself combining with $\mathrm{H}$ radicals could generate $\mathrm{HNNO}$, which reacts with $\mathrm{NO}$ to form $\mathrm{NO}_{2}$ :

$$
\begin{aligned}
& \mathrm{N}_{2} \mathrm{O}+\mathrm{H}+\mathrm{M} \rightarrow \mathrm{HNNO}+\mathrm{M} \\
& \mathrm{HNNO}+\mathrm{NO} \rightarrow \mathrm{NO}_{2}+\mathrm{HNN}
\end{aligned}
$$

Then, $\mathrm{HNO}_{2}$ as well as $\mathrm{HNO}_{3}$ could be synthesized through reactions involving $\mathrm{HNO}$, $\mathrm{NO}$, and $\mathrm{NO}_{2}$ :

$$
\begin{aligned}
& \mathrm{NO}+\mathrm{OH}+\mathrm{M} \rightarrow \mathrm{HNO}_{2}+\mathrm{M} \\
& \mathrm{HNO}+\mathrm{NO}_{2} \rightarrow \mathrm{HNO}_{2}+\mathrm{NO} \\
& \mathrm{HNO}_{2}+\mathrm{NO}_{2} \rightarrow \mathrm{HNO}_{3}+\mathrm{NO} \\
& \mathrm{NO}_{2}+\mathrm{OH}+\mathrm{M} \rightarrow \mathrm{HNO}_{3}+\mathrm{M}
\end{aligned}
$$

On the other hand, $\mathrm{HNO}_{2}$ and $\mathrm{HNO}_{3}$ could also be synthesized in aqueous phase once HNO produced from R20 dissolves in water. Then $\mathrm{HNO}$ dissociates to form $\mathrm{N}_{\mathrm{x}} \mathrm{O}_{\mathrm{x}}{ }^{-}$species, which decay into products, as is showed in Mancinelli and McKay (1988) and Summers and Khare (2007):

$$
\begin{aligned}
& \mathrm{HNO} \rightarrow \mathrm{H}^{+}+\mathrm{NO}^{-} \\
& \mathrm{NO}^{-}+\mathrm{NO} \rightarrow \mathrm{N}_{2} \mathrm{O}_{2}^{-} \\
& \mathrm{N}_{2} \mathrm{O}_{2}{ }^{-}+\mathrm{NO} \rightarrow \mathrm{N}_{3} \mathrm{O}_{3}^{-} \\
& \mathrm{N}_{\mathrm{x}} \mathrm{O}_{\mathrm{x}}^{-} \rightarrow \mathrm{NO}_{2}{ }^{-}+\mathrm{NO}_{3}{ }^{-}+\mathrm{N}_{2} \mathrm{O}
\end{aligned}
$$

\subsection{Formation of ammonia from $\mathrm{N}_{2} \mathrm{O}$}

If the system is rich in $\mathrm{CO}$, the $\mathrm{HNO}$ can be produced mainly from $\mathrm{NO}$ reacting with $\mathrm{HCO}$ radicals rather than the reaction with $\mathrm{H}(\mathrm{R} 20)$ :

$$
\mathrm{NO}+\mathrm{HCO} \rightarrow \mathrm{CO}+\mathrm{HNO}
$$

The rate constant of R32 is about $1.35 \times 10^{-11} \mathrm{~cm}^{3} \mathrm{molec}^{-1} \mathrm{~s}^{-1}$ at room temperature (Dammeier et al., 2007), and in our experiment, estimated reaction rate of R32 is $1.89 \times 10^{13} \mathrm{molec} /\left(\mathrm{cm}^{3} \cdot \mathrm{s}\right)$, which is 10 times faster than that of R20 $\left(5.86 \times 10^{12}\right.$ molec/( $\left.\mathrm{cm}^{3} \cdot \mathrm{s}\right)$ ). Then, the main $\mathrm{N}$-bearing products should be $\mathrm{HNO}_{2}$ and $\mathrm{HNO}_{3}$ via reaction pathways from [R21] to [R31] discussed in section 4.4. However, in the experiment of $\mathrm{N}_{2} \mathrm{O}+\mathrm{CO}+\mathrm{H}_{2} \mathrm{O}, \mathrm{HNO}_{2}$ and $\mathrm{HNO}_{3}$ were not detected either in (A) or in (B) (Table 1, Fig. 2). Instead, $\mathrm{NH}_{4}{ }^{+}$and other reducing $\mathrm{N}$-bearing species such as amino acids were produced.

The production pathway to form $\mathrm{NH}_{4}{ }^{+}$from $\mathrm{N}_{2} \mathrm{O}$ is largely uncertain. A possible 
route to form $\mathrm{NH}_{3}$ is starting from $\mathrm{N}$ atom produced predominantly from photodissociation of NO:

$$
\mathrm{NO}+h v \rightarrow \mathrm{N}+\mathrm{O}
$$

Then, $\mathrm{N}$ atom may combine with $\mathrm{H}$ or $\mathrm{H}_{2}$ to generate $\mathrm{NH}, \mathrm{NH}_{2}$ and $\mathrm{NH}_{3}$ :

$$
\begin{aligned}
& \mathrm{N}+\mathrm{H}+\mathrm{M} \rightarrow \mathrm{NH}+\mathrm{M} \\
& \mathrm{N}+\mathrm{H}_{2}+\mathrm{M} \rightarrow \mathrm{NH}_{2}+\mathrm{M} \\
& \mathrm{NH}_{2}+\mathrm{H}+\mathrm{M} \rightarrow \mathrm{NH}_{3}+\mathrm{M}
\end{aligned}
$$

In order to test this possibility, we constructed a photochemical model including all reactions mentioned above and over 300 related reactions based on NIST database (Version 7.0) to run a numerical calculation under the same initial conditions of experiment $\mathrm{N}_{2} \mathrm{O}+\mathrm{CO}+\mathrm{H}_{2} \mathrm{O}$. Reactions included in the model are listed in Appendix. In this model, produced $\mathrm{NH}_{3}$ are assumed to be dissolved into the liquid water and thus escaped from photodissociation. As a result, however, the model yields only small amount of $\mathrm{NH}_{3}$ (Fig. 4a), which is much less than the experimental results (Fig. 4b), although the amount of major species $\left(\mathrm{CO}_{2}, \mathrm{~N}_{2}, \mathrm{H}_{2}\right)$ was consistent with the experiment. In the model, produced $\mathrm{HNO}_{2}$ and $\mathrm{HNO}_{3}$ were much larger than $\mathrm{NH}_{3}$. The model results indicate that the reaction pathway from $\mathrm{R} 33$ to $\mathrm{R} 36$ is not a major route to form $\mathrm{NH}_{3}$, which is produced through additional mechanism not considered in the model.

One of the possible explanations is that our photochemical model only considered reactions in gas phase, yet $\mathrm{NH}_{3}$ formation driven by UV partly takes place in aqueous solution. If so, when UV light was only irradiated to the gas phase, the amount of $\mathrm{NH}_{3}$ should be less than experiment $\mathrm{N}_{2} \mathrm{O}+\mathrm{CO}+\mathrm{H}_{2} \mathrm{O}$ (A). With this thought, additional experiment $\left(\mathrm{N}_{2} \mathrm{O}+\mathrm{CO}+\mathrm{H}_{2} \mathrm{O}\right.$ (B)) was designed to irradiate $\mathrm{UV}$ horizontally and thus avoid UV chemistry in the solution. However, as is showed in Fig.2, the production of $\mathrm{NH}_{4}^{+}$in the experiment (B) was of the same order of that in the experiment $\mathrm{N}_{2} \mathrm{O}+\mathrm{CO}+\mathrm{H}_{2} \mathrm{O}(\mathrm{A})$. This result indicates that UV chemistry in aqueous phase is not important to produce and that $\mathrm{NH}_{3}$ could be produced in the gas phase. In actual experiment, dissolution of $\mathrm{NH}_{3}$ into liquid water may prohibit further loss of ammonia by photo-dissociation.

Alternatively, presence of $\mathrm{CO}$ may contribute to the formation of $\mathrm{NH}_{3}$. In order to figure out if $\mathrm{CO}$ is involved in the reaction pathway to produce $\mathrm{NH}_{3}$, we conduct $\mathrm{UV}$ experiments starting from $\mathrm{N}_{2} \mathrm{O}$ and $\mathrm{H}_{2}$ with liquid water (EXP-6A, Table 2). The results show that both oxidizing products $\left(\mathrm{NO}_{2}^{-}\right.$and $\left.\mathrm{NO}_{3}{ }^{-}\right)$and reducing product $\left(\mathrm{NH}_{4}{ }^{+}\right)$were 
produced during the first 5 hours, and after 8 hours' irradiation, only $\mathrm{NH}_{4}{ }^{+}$was detected. These results demonstrated that $\mathrm{NH}_{3}$ can be synthesized without $\mathrm{CO}$ and other carbon species. For the ammonium formation, both $\mathrm{CO}$ and $\mathrm{H}_{2}$ may work as reducing agents.

\subsection{Formation of amino acids}

In the experiment $\mathrm{N}_{2} \mathrm{O}+\mathrm{CO}+\mathrm{H}_{2} \mathrm{O}$, methylamine $\left(\mathrm{CH}_{3} \mathrm{NH}_{2}\right)$ and simple amino acids such as glycine, serine and $\beta$-alanine were produced. It is noticed that when UV-light is irradiated only to the gas phase (experiment $\mathrm{B}$ ), the product yields of $\mathrm{CH}_{3} \mathrm{NH}_{2}$ and amino acids are 10 times less than that when UV-light is irradiated to liquid phase (experiment A) as is showed in Fig2. This difference could be explained by either because they were destroyed by UV light before they escape to the water in experiment B, or amino acids are synthesized in aqueous phase rather than in gas phase.

Nishizawa and Egami (1982) pointed out a route to synthesize $\alpha$-amino acids through $\mathrm{N}$-acyl amino acids, which can be produced from $\mathrm{NH}_{3}$ and glyoxylic acid as follows:

$$
\begin{aligned}
& 2 \mathrm{CHO}-\mathrm{COOH}+\mathrm{NH}_{3} \rightarrow \mathrm{HOOC}-\mathrm{CO}-\mathrm{NH}-\mathrm{CH}_{2}-\mathrm{COOH} \\
& \stackrel{\mathrm{H}_{3} \mathrm{O}^{+}}{\longrightarrow} \mathrm{Gly}+(\mathrm{COOH})_{2}
\end{aligned}
$$

this reaction could occur even at room temperature under UV irradiation in neutral or weak acidic aqueous solution and obtain a $20 \%$ yield. In our experiment, the amount of $\mathrm{NH}_{3}$ and glyoxylic acid is 10 times more than that of glycine, and initial solution is neutral, thus it is possible that glycine could also be synthesized through [R37] in aqueous solution.

We conducted a control experiment starting from mixture solution of $1 \mathrm{mM} \mathrm{NH}_{3}$ and $5 \mathrm{mM}$ glycolic acid, with $\mathrm{N}_{2}$ or $\mathrm{CO}$ filled in the gas phase to see whether this reaction could actually happen under our experimental conditions. The results showed that glycine was formed only when the gas phase contained CO (EXP-7A 10A, Table 3), yet the product yield of glycine was only about $0.0021 \%$ of the initial glyoxylic acid, which cannot completely explain the production amount of glycine in the experiment of $\mathrm{N}_{2} \mathrm{O}+\mathrm{CO}+\mathrm{H}_{2} \mathrm{O}$. In the experiment of $\mathrm{NH}_{3}+$ glycolic acid, the initial $\mathrm{pH}$ of solution is 2.92 , in such strong acidic solution reaction [R37] can be negligible. Thus, UV irradiation to mixed solution of $\mathrm{NH}_{3}$ glycolic acid is not efficient to synthesize glycine in our experiment. The amino acids were not produced mainly from $\mathrm{NH}_{3}$ but from $\mathrm{N}_{2} \mathrm{O}$ and/or its derivatives. This is also supported by an additional experiment started from $\mathrm{CO}+\mathrm{NH}_{3}$ 
(EXP-11A, Table3), yielding no detectable amino acids.

On the other hand, glycine may also be produced from $\mathrm{CH}_{3} \mathrm{NH}_{2}$ and $\mathrm{CO}_{2}$, which is demonstrated experimental study mimicking interstellar UV reaction on ice grain (Holtom et al., 2005; Bossa et al., 2009; Lee et al., 2009; Suzuki et al., 2016; Aponte et al., 2017). It may be possible that under the solar-like $\mathrm{UV} \mathrm{CO}$ can addict to $\mathrm{CH}_{3} \mathrm{NH}_{2}$ to synthesize glycine by the following reaction:

$$
\mathrm{CH}_{3} \mathrm{NH}_{2}+\mathrm{CO}_{2} \rightarrow \mathrm{NH}_{2}-\mathrm{CH}_{2}-\mathrm{COOH}
$$

In our experiment, $\mathrm{CO}_{2}$ is the main product in gas and $\mathrm{CH}_{3} \mathrm{NH}_{2}$ is the second abundant products of $\mathrm{N}$-bearing species in aqueous solution. The $\mathrm{CO}_{2}$ and $\mathrm{CH}_{3} \mathrm{NH}_{2}$ could be combined to synthesize glycine. To test the reaction [R38], we conducted an additional UV experiment using $1.0 \mathrm{mM} \mathrm{CH}_{3} \mathrm{NH}_{2} \cdot \mathrm{HCl}$ solution (initial $\mathrm{pH}=7.60$ ) and $\mathrm{CO}_{2}$ gas. As a result, about $1.6 \%$ of starting $\mathrm{CH}_{3} \mathrm{NH}_{2}$ was converted into glycine after $12 \mathrm{~h}$ (EXP-12A, Table 4.). In this experiment, production of glycine was on going at $12 \mathrm{~h}$ and not equilibrated, though the $>1.6 \%$ conversion may be comparable to those in the $\mathrm{N}_{2} \mathrm{O}+\mathrm{CO}+\mathrm{H}_{2} \mathrm{O}$ experiment (Table 1). Therefore, [R38] could be the main route of the glycine formation, although it is largely uncertain for the production of the other minor amino acids (serine and alanine).

\section{Conclusions}

Our experiments demonstrated a new process for the first time that $\mathrm{NH}_{3}$ as well as simple amino acids such as glycine, serine and alanine can be synthesized from gas mixture of $\mathrm{N}_{2} \mathrm{O}, \mathrm{CO}$ and $\mathrm{H}_{2} \mathrm{O}$ by solar-like photochemistry without catalyst. They can be produced in gas phase, and could be protected from photolytic destruction in liquid water.

The mechanism of $\mathrm{NH}_{3}$ formation is largely uncertain, though $\mathrm{N}_{2} \mathrm{O}$ can be converted into $\mathrm{NH}_{3}$ when appropriate reducing agent $\left(\mathrm{CO}\right.$ or $\left.\mathrm{H}_{2}\right)$ is available. Although we examine a few possible reaction pathways to form $\mathrm{NH}_{3}$, the production mechanism of $\mathrm{NH}_{3}$ is not yet explained quantitatively. There may be other unknown reactions to generate $\mathrm{NH}_{3}$ in gas phase, or $\mathrm{NH}_{3}$ could be produced by reduction from $\mathrm{NO}_{2}^{-}$and $\mathrm{NO}_{3}^{-}$via aqueous reactions.

On the other hand, glycine could be formed through the $\mathrm{CO}_{2}$ addiction to $\mathrm{CH}_{3} \mathrm{NH}_{2}$, which can be produced from $\mathrm{N}_{2} \mathrm{O}$ and $\mathrm{CO}$ under solar-live UV irradiation. In addition, glycine may possibly be produced from glyoxylic acid and ammonia (Nishizawa and Egami,1982), though the route is not the main reaction in our UV experiment. 
Previously, $\mathrm{N}_{2} \mathrm{O}$ has not been considered as a main nitrogen source that could generate building blocks of life on primitive Earth, where amino acids have been considered to come from lightning of $\mathrm{N}_{2}$ atmosphere, hydrothermal production and/or from space by meteorite impact. Atmospheric synthesis from $\mathrm{N}_{2} \mathrm{O}$ could be an additional or even more efficient process to provide amino acids. The atmospheric $\mathrm{N}_{2} \mathrm{O}$ level in early atmosphere is largely uncertain, though potentially 10 times higher than today (Airapetian et al., 2016). Therefore, photochemical production of organic matters from $\mathrm{N}_{2} \mathrm{O}$ should be considered when discussing the chemical evolution before the first life arose. Our study demonstrated that $\mathrm{N}_{2} \mathrm{O}$ could be an important nitrogen source and could provide a new process for synthesizing organic nitrogen species that was not considered before.

\section{Acknowledgement}

The authors thank W. Kawade and Y. Endo for support in conducting experiments and in the discussion. This work was financially supported by JSPS Kakenhi 17 H01176 and 16H04073 for Y.U. 


\section{References}

Ahumada J. J., Michael J. V., and Osborne D. T. (1972) Pressure Dependence and Third Body Effects on the Rate Constants for $\mathrm{H}+\mathrm{O}_{2}, \mathrm{H}+\mathrm{NO}$, and $\mathrm{H}+\mathrm{CO}$. The Journal of Chemical Physics, 57: 3736-3745.

Airapetian V. S., Glocer A., Gronoff G., Hébrard E., and Danchi W. (2016) Prebiotic chemistry and atmospheric warming of early Earth by an active young Sun. Nature Geoscience, 9: 452-455.

Aponte J. C., Elsila J. E., Glavin D. P., Milam S. N., Charnley S. B., and Dworkin J. P. (2017) Pathways to Meteoritic Glycine and Methylamine. ACS Earth Space Chem, 1: 3-13.

Bar-Nun A., Bar-Nun N., Bauerm S. H., and Sagan C. (1970) Shock Synthesis of Amino Acids in Simulated Primitive Environments. Science, 168: 470-472.

Bar-Nun A., and Chang S. (1983) Photochemical reactions of water and carbon monoxide in Earth's primitive atmosphere. Journal of geophysical research, 88: 6662-6672.

Baulch D. L., Cobos C. J., Cox R. A., Frank P., Hayman G., Just T., Kerr J. A., Murrells T., Pilling M. J., Troe J. and others. (1994) Evaluated Kinetic Data for Combustion Modeling. Supplement I. Journal of Physical and Chemical Reference Data, 23: 847-848.

Bossa J. B., Duvernay F., Theulé P., Borget F., d'Hendecourt L., and Chiavassa T. (2009) Methylammonium methylcarbamate thermal formation in interstellar ice analogs: a glycine salt precursor in protostellar environments. Astronomy \& Astrophysics, 506: 601608.

Brandes J. A., Boctor N. Z., Cody G. D., Cooper B. A., Hazen R. M., and Yoder Jr H. S. (1998) Abiotic nitrogen reduction on the early Earth. Nature, 395: 365-367.

Brandes J. A., Hazen R. M., and Yoder Jr H. S. (2008) Inorganic nitrogen reduction and stability under simulated hydrothermal conditions. Astrobiology, 8: 1113-26.

Calvert J. G., and Pitts J. N. (1966) Photochemistry. John Wiley, New York.

Chyba C., and Sagan C. (1991) Electrical energy sources for organic synthesis on the early Earth.

Dammeier J., Colberg M., and Friedrichs G. (2007) Wide temperature range (T = $295 \mathrm{~K}$ and 770-1305 K) study of the kinetics of the reactions $\mathrm{HCO}+\mathrm{NO}$ and $\mathrm{HCO}+\mathrm{NO}_{2}$ using frequency modulation spectroscopy. Phys Chem Chem Phys, 9: 4177-4188.

Demore W. B., Sander S. P., Golden D. M., Hampson R. F., Kurylo M. J., Howard C. J., Ravishankara A. R., Kolb C. E., and Molina M. J. (1992) Chemical kinetics and photochemical data for use in stratospheric modeling.

Eugster H. P., and Munoz J. (1966) Ammonium Micas: Possible Sources of Atmospheric 
Ammonia and Nitrogen. Science, 151: 683-686.

Groth W. E., and Weyssenhoff H. v. (1960) Photochemical formation of organic compounds from mixtures of simple gases. Planetary and Space Science, 2: 79-85.

Hikida T., Eyre J. A., and Dorfman L. M. (1971) Pulse Radiolysis Studies. XX. Kinetics of Some Addition Reactions of Gaseous Hydrogen Atoms by Fast Lyman - $\alpha$ Absorption Spectrophotometry. The Journal of Chemical Physics, 54: 3422-3428.

Hochanadel C. J., Sworski T. J., and Ogren P. J. (1980) Ultraviolet spectrum and reaction kinetics of the formyl radical. The Journal of Physical Chemistry, 84: 231-235.

Holtom P. D., Bennett C. J., Osamura Y., Mason N. J., and Kaiser R. I. (2005) A COMBINED EXPERIMENTAL AND THEORETICAL STUDY ON THE FORMATION OF THE AMINO ACID GLYCINE (NH2CH2COOH) AND ITS ISOMER (CH3NHCOOH) IN EXTRATERRESTRIAL ICES. The astrophysical Journal, 626: 940-952.

Kasting J. F. (1993) Earth's early atmosphere. Science, 259: 920-926.

Kobayashi K., Kaneko T., and Saito T. (1999) Characterization of complex organic compounds formed in simulated planetary atmospheres by the action of high energy particles. Advances in Space Research, 24: 461-464.

Kobayashi K., Kaneko T., Saito T., and Oshima T. (1998) Amino acid formation in gas mixtures by high energy particle irradiation. Origins of Life and Evolution of the Biosphere, 28: 155-165.

Kobayashi K., Oshima T., and Yanagawa H. (1989) Abiotic Synthesis of Amino Acids by Proton Irradiation of a Mixture of Carbon Monoxide, Nitrogen, and Water. Chemistry Letters, 18: $1527-1530$.

Kobayashi K., Tsuchiya M., Oshima T., and Yanagawa H. (1990) Abiotic synthesis of amino acids and imidazole by proton irradiation of simulated primitive earth atmospheres. Origins of Life and Evolution of the Biosphere, 20: 99-109.

Laneuville M., Kameya M., and Cleaves H. J. I. (2018) Earth Without Life: A Systems Model of a Global Abiotic Nitrogen Cycle. Astrobiology, 18: 897-914.

Lee C. W., Kim J. K., Moon E. S., Minh Y. C., and Kang H. (2009) Formation of Glycine on Ultraviolet-Irradiated Interstellar Ice-Analog Films and Implications for Interstellar Amino Acids. The Astrophysical Journal, 697: 428-435.

Lowe C. U., and Rees M. W. Markham Dr.R. F.R.S. (1963) Synthesis of Complex Organic Compounds from Simple Precursors: Formation of Amino-Acids, Amino-Acid Polymers, Fatty Acids and Purines from Ammonium Cyanide. Nature, 199: 219-222. 
Mancinelli R. L., and McKay C. P. (1988) The evolution of nitrogen cycling. Orings of life and evolution of the biosphere, 18: 311-325.

Miller S. L. (1953) A production of amino acids under possible primitive Earth conditions. Science, 117: 528-529.

Miller S. L. (1955) Production of some organic compounds under possible primitive Earth conditions. Journal of the american chemical society, 77: 2351-2361.

Miller S. L., and Urey H. C. (1959) Organic compound synthesis on the primitive Earth. Science, 130: $245-251$.

Nishizawa M., and Egami F. (1982) An Experimental Approach to the Prebiotic Synthesis of $\alpha$ -Amino Acids under UV Irradiation in Aqueous Medium. The Chemical Society of Japan, 55: 2689-2690.

Nna Mvondo D., Navarro-Gonzalez R., McKay C. P., Coll P., and Raulin F. (2001) Production of nitrogen oxides by lightning and coronae discharges in simulated early Earth, Venus and Mars environments. 27: 217-223.

Nna Mvondo D., Navarro-Gonzalez R., Raulin F., and Coll P. (2005) NITROGEN FIXATION BY CORONA DISCHARGE ON THE EARLY PRECAMBRIAN EARTH. Origins of Life and Evolution of Biospheres, 35: 401-409.

Nuevo M., Bredehöft J. H., Meierhenrich U. J., d'Hendecourt.L, and Thiemann W. P. (2010) Urea, Glycolic Acid, and Glycerol in an Organic Residue Produced by Ultraviolet Irradiation of Interstellar=Pre-Cometary Ice Analogs. Astrobiology, 10: 245-256.

Oro’ J., Kimball A., Fritz R., and Master F. (1959) Amino acid synthesis from formaldehyde and hydroxylamine. Archives of Biochemistry and Biophysics, 85: 115-130.

Pavlov A. A., Brown L. L., and Kasting J. F. (2001) UV shielding of NH3 and O2 by organic hazes in the Archean atmosphere. JOURNAL OF GEOPHYSICAL RESEARCH, 106: 267-288.

Prakash M. K., Weibel J. D., and Marcus R. A. (2005) Isotopomer fractionation in the UV photolysis of $\mathrm{N}_{2} \mathrm{O}$ : Comparison of theory and experiment. Journal of Geophysical Research, 110.

Preston K. F., and Barr R. F. (1971) Primary Processes in the Photolysis of Nitrous Oxide. The Journal of Chemical Physics, 54: 3347-3348.

Sagan C., and Khare B. N. (1971) Long-Wavelength Ultraviolet Photoproduction of Amino Acids on the Primitive Earth. Science, 173: 417-420.

Schlesinger G., and Miller S. (1983) Prebiotic synthesis in atmospheres containing $\mathrm{CH}_{4}, \mathrm{CO}$ and 
$\mathrm{CO}_{2}$. Journal of molecular evolutoin, 19: 376-382.

Schmidt J. A., Johnson M. S., Lorenz U., McBane G. C., and Schinke R. (2011) Photodissociation of N2O: energy partitioning. J Chem Phys, 135: 024311.

Schoonen M. A., and Xu Y. (2001) Nitrogen Reduction Under Hydrothermal Vent Conditions: Implications for the Prebiotic Synthesis of C-H-O-N Compounds. Astrobiology, 1: 133142.

Singireddy S., Gordon A. D., Smirnov A., Vance M. A., Schoonen M. A., Szilagyi R. K., and Strongin D. R. (2012) Reduction of nitrite and nitrate to ammonium on pyrite. Orig Life Evol Biosph, 42: 275-94.

Smirnov A., Hausner D., Laffers R., Strongin D. R., and Schoonen M. A. (2008) Abiotic ammonium formation in the presence of Ni-Fe metals and alloys and its implications for the Hadean nitrogen cycle. Geochem Trans, 9: 5.

Summers D., and Chang S. (1993) Prebiotic ammonia from reduction of nitrite by iron (II) on the early Earth. Nature, 365: 630-633.

Summers D. P. (2005) Ammonia formation by the reduction of nitrite/nitrate by FeS: ammonia formation under acidic conditions. Origins of life and Evolution of Biospheres, 35: 299312.

Summers D. P., Basa R. C., Khare B., and Rodoni D. (2012) Abiotic nitrogen fixation on terrestrial planets: reduction of NO to ammonia by FeS. Astrobiology, 12: 107-14.

Summers D. P., and Khare B. (2007) Nitrogen fixation on early Mars and other terrestrial planets: experimental demonstration of abiotic fixation reactions to nitrite and nitrate. Astrobiology, 7: 333-41.

Suzuki T., Ohishi M., Hirota T., Saito M., Majumdar L., and Wakelam V. (2016) Survey Observations of a Possible Glycine Precursor, Methanimine $\left(\mathrm{CH}_{2} \mathrm{NH}\right)$. The Astrophysical Journal, 825, 79 .

Utsumi Y., and Takahashi J. (1998) Synthesis of Amino Acids from N2, H2O Vapor and CO2 Gas Mixture by Synchrotron Radiation Induced Photochemical Reactions at Atmospheric Pressure. Japanese Journal of Applied Physics, 37: 1268-1270.

Walker J. C. G. (1985) Carbon dioxide on the early Earth. Origins of life and evolution of the biosphere, 16: 117-127.

Walker J. C. G., and Mendillo M. (1977) Evolution of the Atmosphere. Physics Today, 32: 7174.

Yetter R. A., Rabitz H., Dryer F. L., Maki R. G., and Klemm R. B. (1989) Evaluation of the rate 
constant for the reaction $\mathrm{OH}+\mathrm{H} 2 \mathrm{CO}$ : Application of modeling and sensitivity analysis techniques for determination of the product branching ratio. The Journal of Chemical Physics, 91: 4088-4097.

Yung Y. L., Drew W. A., Pinto J. P., and Friedl R., R. (1988) Estimation of the reaction rate for the formation of $\mathrm{CH}_{3} \mathrm{O}$ from $\mathrm{H}+\mathrm{H}_{2} \mathrm{CO}$ : Implications for chemistry in the solar system. Icarus, 73: 516-526.

Yung Y. L., and Mcelroy M. B. (1979) FixationofNitrogeninthePrebioticAtmosphere. Science, 203: 1002-1004. 


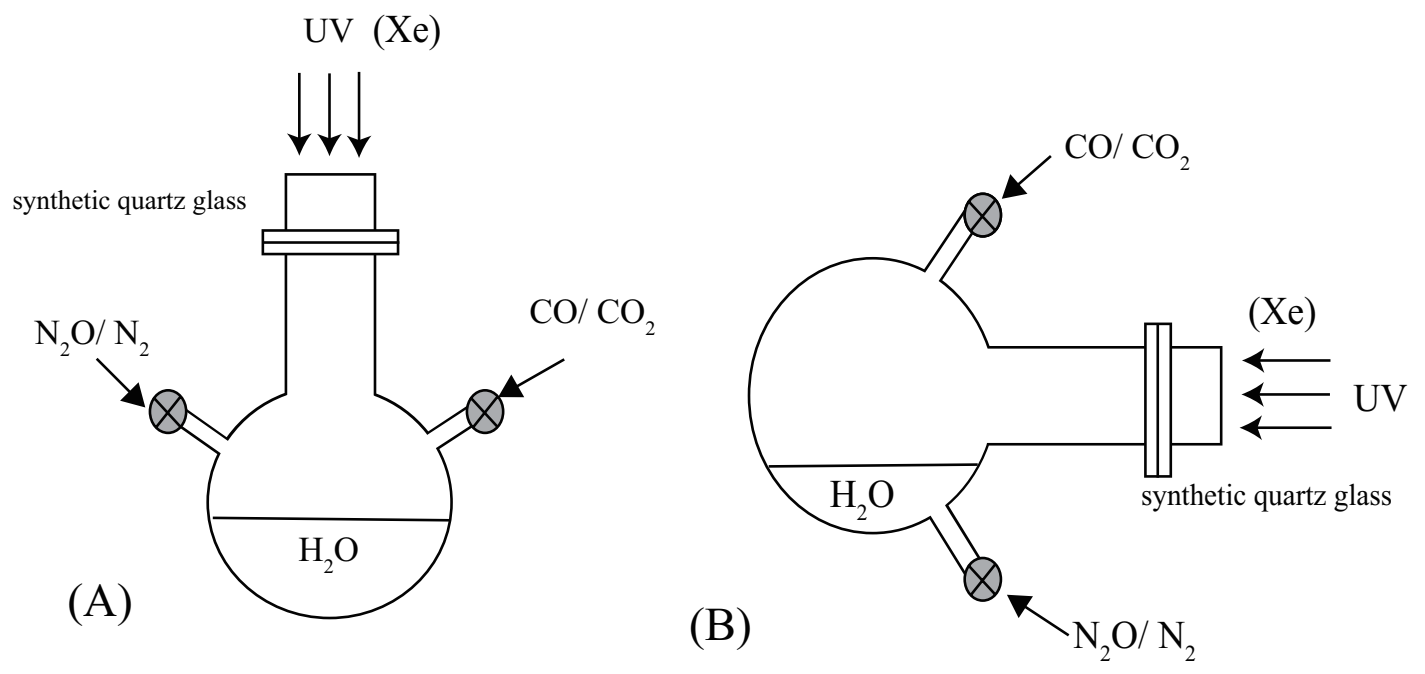

Figure 1. Outline of experimental apparatus. (A) UV light irradiated vertically from the top to the surface of liquid water; (B) UV light irradiated horizontally, only into the gas phase.

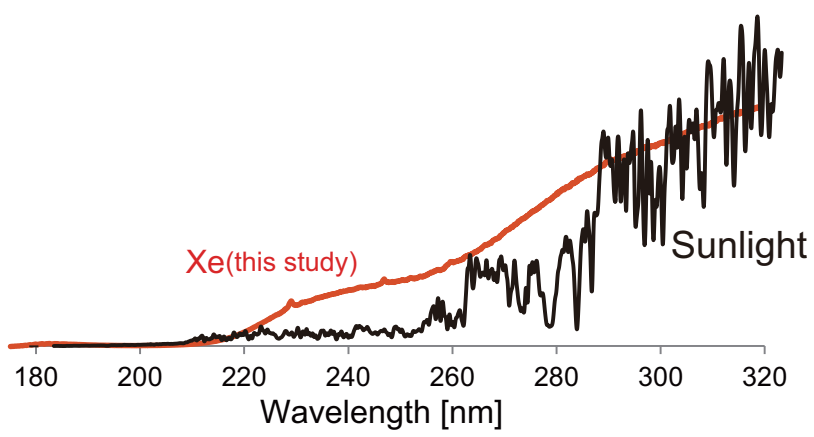

Figure 2. The spectrum of Xe lamp used in the experiments, which is close to the natural sunlight to simulate the ultraviolet light from the Sun. 

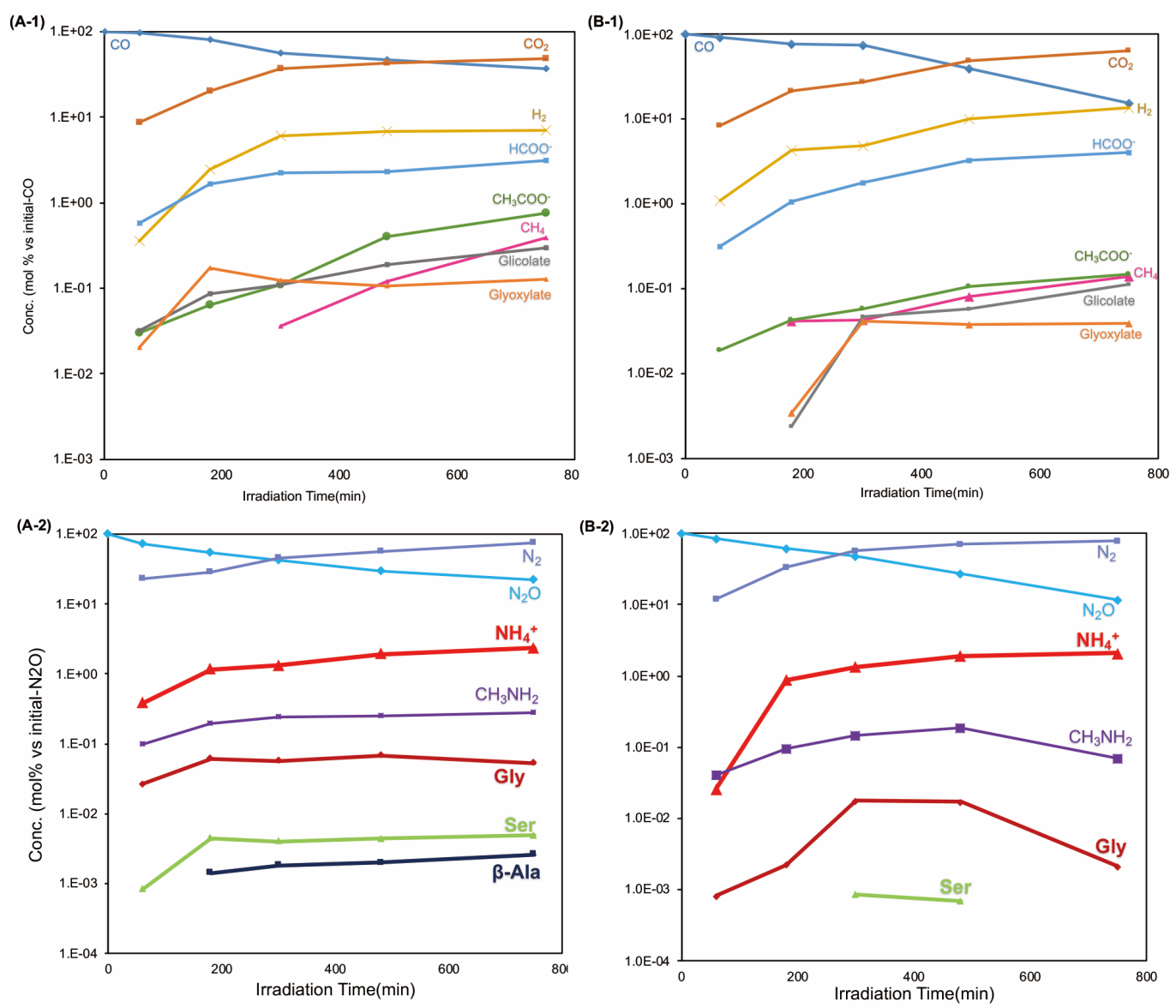

Figure 3. Products yields relative to initial carbon (above) or initial nitrogen (below) as a function of irradiation time (min). (A-1) and (A-2) show results of the experiment $\mathrm{N}_{2} \mathrm{O}+\mathrm{CO}+\mathrm{H}_{2} \mathrm{O}(\mathrm{A})$, (B-1) and (B-2) show results of the experiment $\mathrm{N}_{2} \mathrm{O}+\mathrm{CO}+\mathrm{H}_{2} \mathrm{O}(\mathrm{B})$. The $\mathrm{Y}$ axis are scaled logarithmically. 
(a)

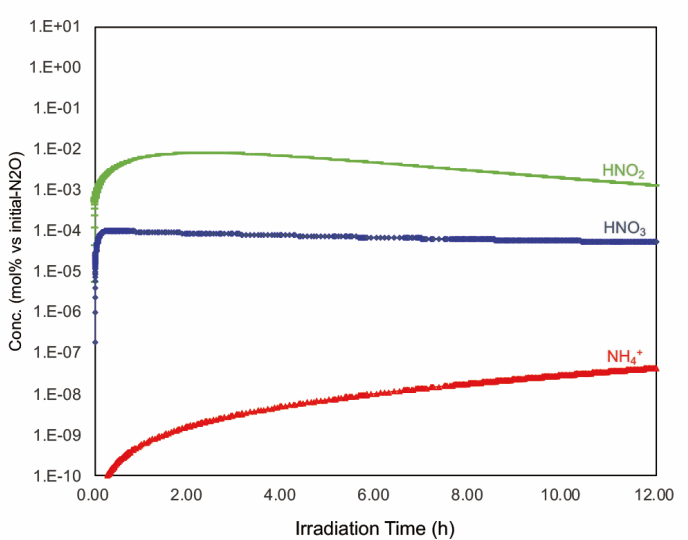

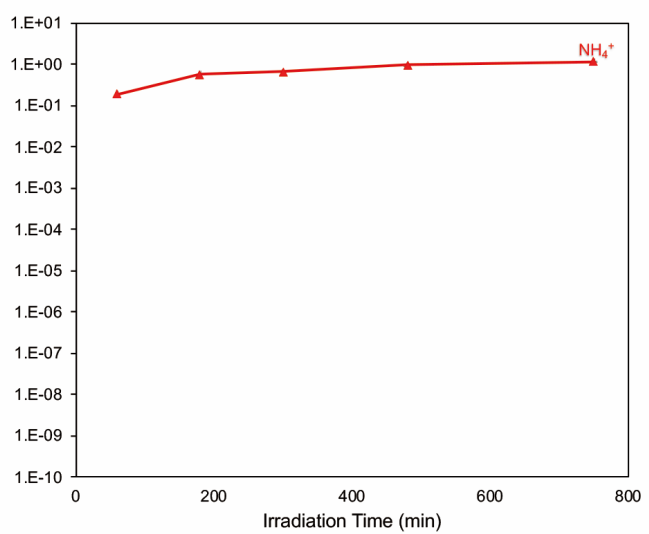

Figure 4. Results of numerical calculation compared with experimental results. (a) shows the calculation results of our photochemical model, and (b) shows the results of UV experiment of $\mathrm{N}_{2} \mathrm{O}+\mathrm{CO}+\mathrm{H}_{2} \mathrm{O}$ (b). The $\mathrm{Y}$ axis are scaled logarithmically.

\begin{tabular}{|c|c|c|c|c|c|c|c|c|c|c|c|c|c|c|c|c|c|c|c|c|c|c|c|c|c|c|}
\hline \multirow{2}{*}{ Experiment $^{\mathrm{a}}$} & \multirow{2}{*}{$\begin{array}{l}\text { Time } \\
\text { [min.] }\end{array}$} & \multicolumn{2}{|c|}{$\mathrm{H}_{2} \mathrm{O}$ Flask } & \multirow{2}{*}{$\begin{array}{c}\text { Gas } \\
{[\mathrm{ml}]}\end{array}$} & \multicolumn{4}{|c|}{ Initial gas species $[\mu \mathrm{mol}]$} & \multicolumn{7}{|c|}{ Final gas species $[\mu \mathrm{mol}]$} & \multicolumn{11}{|c|}{ Final dissolved species $[\mu \mathrm{mol}]$} \\
\hline & & [ml] & {$[\mathrm{ml}]$} & & co & $\mathrm{CO}_{2}$ & $\mathrm{~N}_{2} \mathrm{O}$ & $\mathrm{N}_{2}$ & co & $\mathrm{CO}_{2}$ & $\mathrm{~N}_{2} \mathrm{O}$ & $\mathrm{N}_{2}$ & $\mathrm{O}_{2}$ & $\mathrm{H}_{2}$ & $\mathrm{CH}_{4}$ & $\mathrm{NO}_{2}{ }^{-}$ & $\mathrm{NO}_{3}{ }^{\circ}$ & $\mathrm{NH}_{4}^{+}$ & Formate & Asctate & Gisoluse & 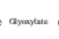 & $\mathrm{CH}_{\mathrm{NH}}$ & Glycine & B-Alanin & Serine \\
\hline EXP-1 A N ${ }_{2} \mathrm{O}+\mathrm{CO}+\mathrm{H}_{2} \mathrm{O}$ & 60 & 50 & 430 & 380 & 1399 & n.d. & 470 & n.d. & 1357 & 121 & 343 & 110 & n.d. & 5.0 & n.d. & n.d. & n.d. & 1.81 & 8.02 & 0.21 & 0.22 & 0.14 & 0.46 & 0.124 & n.d. & 0.004 \\
\hline $\mathrm{N}_{2} \mathrm{O}+\mathrm{CO}+\mathrm{H}_{2} \mathrm{O}$ & 180 & 50 & 430 & 380 & 1342 & n.d. & 485 & n.d. & 1087 & 272 & 263 & 137 & n.d. & 33.1 & n.d. & n.d. & n.d. & 5.63 & 22.06 & 0.43 & 0.58 & 1.14 & 0.94 & 0.296 & 0.007 & 0.022 \\
\hline $\mathrm{N}_{2} \mathrm{O}+\mathrm{CO}+\mathrm{H}_{2} \mathrm{O}$ & 300 & 50 & 430 & 380 & 1062 & n.d. & 532 & n.d. & 596 & 386 & 226 & 242 & n.d. & 64.3 & 0.38 & n.d. & n.d. & 7.02 & 23.74 & 0.57 & 0.57 & 0.66 & 1.30 & 0.306 & 0.010 & 0.021 \\
\hline $\mathrm{N}_{2} \mathrm{O}+\mathrm{CO}+\mathrm{H}_{2} \mathrm{O}$ & 480 & 50 & 430 & 380 & 1406 & n.d. & 516 & n.d. & 669 & 608 & 154 & 297 & n.d. & 96.9 & 1.70 & n.d. & n.d. & 9.91 & 32.06 & 2.77 & 1.32 & 0.74 & 1.29 & 0.355 & 0.010 & 0.023 \\
\hline $\mathrm{N}_{2} \mathrm{O}+\mathrm{CO}+\mathrm{H}_{2} \mathrm{O}$ & 750 & 50 & 449 & 399 & 1771 & n.d. & 489 & n.d. & 659 & 847 & 107 & 365 & n.d. & 123.5 & 6.89 & n.d. & n.d. & 11.42 & 55.42 & 6.76 & 2.63 & 1.12 & 1.36 & 0.260 & 0.013 & 0.024 \\
\hline EXP-1B N $\mathrm{N}_{2} \mathrm{O}+\mathrm{CO}+\mathrm{H}_{2} \mathrm{O}$ & 60 & 20 & 430 & 410 & 1219 & n.d. & 430 & n.d. & 1135 & 101 & 360 & 52 & n.d. & 13.2 & n.d. & n.d. & n.d. & 0.11 & 3.80 & 0.11 & n.d. & n.d. & 0.18 & 0.004 & n.d. & n.d. \\
\hline $\mathrm{N}_{2} \mathrm{O}+\mathrm{CO}+\mathrm{H}_{2} \mathrm{O}$ & 180 & 20 & 430 & 410 & 1224 & n.d. & 420 & n.d. & 932 & 262 & 254 & 144 & n.d. & 52.6 & 0.51 & n.d. & n.d. & 3.71 & 13.18 & 0.26 & 0.01 & 0.02 & 0.40 & 0.009 & n.d. & n.d. \\
\hline $\mathrm{N}_{2} \mathrm{O}+\mathrm{CO}+\mathrm{H}_{2} \mathrm{O}$ & 300 & 30 & 430 & 400 & 1505 & n.d. & 381 & n.d. & 1118 & 406 & 185 & 217 & n.d. & 74.0 & 0.64 & n.d. & n.d. & 5.16 & 26.89 & 0.43 & 0.36 & 0.31 & 0.57 & 0.067 & n.d. & 0.003 \\
\hline $\mathrm{N}_{2} \mathrm{O}+\mathrm{CO}+\mathrm{H}_{2} \mathrm{O}$ & 480 & 20 & 430 & 410 & 1243 & n.d. & 402 & n.d. & 485 & 608 & 110 & 290 & n.d. & 123.4 & 1.00 & n.d. & n.d. & 7.67 & 40.90 & 0.65 & 0.36 & 0.23 & 0.76 & 0.068 & n.d. & 0.003 \\
\hline $\mathrm{N}_{2} \mathrm{O}+\mathrm{CO}+\mathrm{H}_{2} \mathrm{O}$ & 750 & 20 & 430 & 410 & 1173 & n.d. & 420 & n.d. & 180 & 753 & 49 & 332 & n.d. & 158.6 & 1.62 & n.d. & n.d. & 8.73 & 47.00 & 0.86 & 0.65 & 0.23 & 0.29 & 0.009 & n.d. & n.d. \\
\hline EXP- $2 \mathrm{~A} \mathrm{~N}_{2} \mathrm{O}+\mathrm{H}_{2} \mathrm{O}$ & 60 & 50 & 430 & 380 & n.d. & n.d. & 611 & n.d. & n.d. & n.d. & 519 & $\therefore$ & & n.d. & n.d. & 0.83 & 5.16 & n.d. & n.a. & n.a. & n.a. & n.a. & n.a. & n.a. & n.a. & n.a. \\
\hline $\mathrm{N}_{2} \mathrm{O}+\mathrm{H}_{2} \mathrm{O}$ & 120 & 50 & 430 & 380 & n.d. & n.d. & 518 & n.d. & n.d. & n.d. & 443 & $\because$ & & n.d. & n.d. & 0.55 & 12.05 & n.d. & n.a. & n.a. & n.a. & n.a. & n.a. & n.a. & n.a. & n.a. \\
\hline $\mathrm{N}_{2} \mathrm{O}+\mathrm{H}_{2} \mathrm{O}$ & 300 & 50 & 459 & 409 & n.d. & n.d. & 788 & n.d. & n.d. & n.d. & 224 & $\therefore$ & & n.d. & n.d. & 0.41 & 46.16 & n.d. & n.a. & n.a. & n.a. & n.a. & n.a. & n.a. & n.a. & n.a. \\
\hline $\mathrm{N}_{2} \mathrm{O}+\mathrm{H}_{2} \mathrm{O}$ & 480 & 50 & 459 & 409 & n.d. & n.d. & 973 & n.d. & n.d. & n.d. & 470 & $-^{\circ}$ & & n.d. & n.d. & 0.53 & 46.33 & n.d. & n.a. & n.a. & n.a. & n.a. & n.a. & n.a. & n.a. & n.a. \\
\hline EXP-3A N & 160 & 50 & 457 & 407 & 1709 & n.d. & n.d. & 516 & 1325 & 142 & n.d. & 443 & n.d. & 54.1 & n.d. & n.d. & n.d. & n.d. & 11.71 & 0.28 & 2.37 & 1.12 & n.d. & n.d. & n.d. & n.d. \\
\hline $\mathrm{N}_{2}+\mathrm{CO}+\mathrm{H}_{2} \mathrm{O}$ & 300 & 50 & 457 & 407 & 1275 & n.d. & n.d. & 579 & 778 & 308 & n.d. & 450 & n.d. & 119.6 & 1.13 & n.d. & n.d. & n.d. & 25.84 & 1.00 & 2.17 & 0.55 & n.d. & n.d. & n.d. & n.d. \\
\hline EXP-4A N $\mathrm{N}_{2} \mathrm{O}+\mathrm{CO}_{2}+\mathrm{H}_{2} \mathrm{O}$ & 360 & 50 & 459 & 409 & n.d. & 1591 & 500 & n.d. & n.d. & 1301 & 140 & $\because$ & & n.d. & n.d. & n.d. & n.d. & n.d. & n.d. & n.d. & n.d. & n.d. & n.d. & n.d. & n.d. & n.d. \\
\hline $\mathrm{N}_{2} \mathrm{O}+\mathrm{CO}_{2}+\mathrm{H}_{2} \mathrm{O}$ & 720 & 50 & 459 & 409 & n.d. & 1389 & 497 & n.d. & n.d. & 1279 & 59 & $-\circ$ & & n.d. & n.d. & n.d. & n.d. & n.d. & n.d. & n.d. & n.d. & n.d. & n.d. & n.d. & n.d. & n.d. \\
\hline EXP- $5 \mathrm{~A} \mathrm{~N}_{2}+\mathrm{CO}_{2}+\mathrm{H}_{2} \mathrm{O}$ & 360 & 50 & 459 & 409 & n.d. & 1511 & n.d. & 478 & n.d. & 1349 & n.d. & 456 & n.d. & n.d. & n.d. & n.d. & n.d. & n.d. & n.d. & n.d. & n.d. & n.d. & n.d. & n.d. & n.d. & n.d. \\
\hline $\mathrm{N}_{2}+\mathrm{CO}_{2}+\mathrm{H}_{2} \mathrm{O}$ & 720 & 50 & 459 & 409 & n.d. & 1476 & n.d. & 491 & n.d. & 1403 & n.d. & 577 & n.d. & n.d. & n.d. & n.d. & n.d. & n.d. & n.d. & n.d. & n.d. & n.d. & n.d. & n.d. & n.d. & n.d. \\
\hline
\end{tabular}


Table 2. Results of UV experiments starting from $\mathrm{N} 2 \mathrm{O}$ and $\mathrm{H} 2$ instead of $\mathrm{CO}$.

\begin{tabular}{|c|c|c|c|c|c|c|c|c|c|c|c|c|c|c|}
\hline \multirow{2}{*}{\multicolumn{2}{|c|}{ Experiment }} & \multirow{2}{*}{$\begin{array}{l}\text { Time } \\
\text { [min.] }\end{array}$} & \multirow{2}{*}{$\begin{array}{l}\mathrm{H}_{2} \mathrm{O} \\
{[\mathrm{ml}]}\end{array}$} & \multirow{2}{*}{$\begin{array}{c}\text { Flask V } \\
{[\mathrm{ml}]}\end{array}$} & \multirow{2}{*}{$\begin{array}{r}\text { Gas V } \\
{[\mathrm{ml}]}\end{array}$} & \multicolumn{2}{|c|}{ Initial gas species $[\mu \mathrm{mol}]$} & \multicolumn{4}{|c|}{ Final gas species $[\mu \mathrm{mol}]$} & \multicolumn{3}{|c|}{ Final dissolved species [ $\mu \mathrm{mol}]$} \\
\hline & & & & & & $\mathrm{H}_{2}$ & $\mathrm{~N}_{2} \mathrm{O}$ & $\mathrm{H}_{2}$ & $\mathrm{~N}_{2} \mathrm{O}$ & $\mathrm{N}_{2}$ & $\mathrm{O}_{2}$ & $\mathrm{NH}_{4}^{+}$ & $\mathrm{NO}_{2}^{-}$ & $\mathrm{NO}_{3}{ }^{-}$ \\
\hline \multirow[t]{4}{*}{ EXP-6A } & $\mathrm{N}_{2} \mathrm{O}+\mathrm{H}_{2}+\mathrm{H}_{2} \mathrm{O}$ & 180 & 50 & 430 & 380 & 721 & 519 & 413 & 296.7 & 296 & n.d. & 2.47 & 2.16 & 0.50 \\
\hline & $\mathrm{N}_{2} \mathrm{O}+\mathrm{H}_{2}+\mathrm{H}_{2} \mathrm{O}$ & 300 & 50 & 430 & 380 & 1258 & 947 & 1055 & 532.2 & 692 & n.d. & 1.38 & 10.66 & 2.37 \\
\hline & $\mathrm{N}_{2} \mathrm{O}+\mathrm{H}_{2}+\mathrm{H}_{2} \mathrm{O}$ & 480 & 50 & 430 & 380 & 1901 & 438 & 1431 & 1.3 & 490 & n.d. & 9.07 & n.d. & n.d. \\
\hline & $\mathrm{N}_{2} \mathrm{O}+\mathrm{H}_{2}+\mathrm{H}_{2} \mathrm{O}$ & 750 & 50 & 430 & 380 & 2098 & 735 & 1390 & 0.7 & 903 & n.d. & 11.45 & n.d. & n.d. \\
\hline
\end{tabular}

Table 3. Results of UV experiments starting from ammonium solution with glyoxylic acid or CO .

\begin{tabular}{|c|c|c|c|c|c|c|c|c|c|c|c|c|c|c|c|c|c|c|c|}
\hline \multirow{2}{*}{\multicolumn{2}{|c|}{ Experiment }} & \multicolumn{3}{|c|}{ Time solution Flask } & \multirow{2}{*}{$\begin{array}{l}\text { Gas } \\
{[\mathrm{ml}]}\end{array}$} & \multicolumn{5}{|c|}{ Initial species $[\mu \mathrm{mol}]$} & \multicolumn{9}{|c|}{ Final dissolved species $[\mu \mathrm{mol}]$} \\
\hline & & [min.] & {$[\mathrm{ml}]$} & [ml] & & $\mathrm{CO}$ & $\mathrm{N}_{2}$ & Glyoxylate & $\mathrm{NH}_{4}^{+}$ & Glycine & $\mathrm{pH}$ & $\mathrm{NH}_{4}^{+}$ & Glyoxylate & Formate & e Acetate & e Gikcolate & - Oxalate & e Glycine & $\mathrm{pH}$ \\
\hline \multirow[t]{3}{*}{ EXP-7A } & Glyoxylic acid $+\mathrm{NH}_{4} \mathrm{Cl}(\mathrm{aq})+\mathrm{N}_{2}(\mathrm{~g})$ & 60 & 50 & 430 & 380 & n.d. & 639 & 254.5 & 55.0 & n.d. & 2.92 & 55.5 & 115.6 & 34.12 & 2 n.d. & 1.45 & n.d. & n.d. & 2.92 \\
\hline & Glyoxylic acid $+\mathrm{NH}_{4} \mathrm{Cl}(\mathrm{aq})+\mathrm{N}_{2}(\mathrm{~g})$ & 180 & 50 & 430 & 380 & n.d. & 695 & 254.5 & 55.0 & n.d. & 2.92 & 55.9 & 20.9 & 44.52 & 21.09 & 2.69 & n.d. & n.d. & \\
\hline & Glyoxylic acid $+\mathrm{NH}_{4} \mathrm{Cl}(\mathrm{aq})+\mathrm{N}_{2}(\mathrm{~g})$ & 300 & 50 & 430 & 380 & n.d. & 680 & 254.5 & 55.0 & n.d. & 2.92 & 55.4 & 2.5 & 36.50 & 4.46 & 2.66 & n.d. & n.d. & 3.15 \\
\hline \multirow[t]{2}{*}{ EXP-8A } & Glyoxylic acid $+\mathrm{NH}_{4} \mathrm{Cl}(\mathrm{aq})+\mathrm{CO}(\mathrm{g})$ & 60 & 50 & 430 & 380 & 858 & n.d. & 254.5 & 55.0 & n.d. & 2.92 & 55.5 & 115.5 & 36.06 & 6 n.d. & 1.69 & $-{ }^{\mathrm{c}}$ & 0.0053 & \\
\hline & Glyoxylic acid $+\mathrm{NH}_{4} \mathrm{Cl}(\mathrm{aq})+\mathrm{CO}(\mathrm{g})$ & 240 & 50 & 430 & 380 & 1176 & n.d. & 254.5 & 55.0 & n.d. & 2.92 & 55.8 & 3.3 & 54.03 & 2.19 & 4.49 & $-{ }^{c}$ & 0.0023 & 3.25 \\
\hline EXP-9A & Glyoxylic acid $+\mathrm{NH}_{4} \mathrm{Cl}(\mathrm{aq})+\mathrm{CO}(\mathrm{g}) \_$No UV & 1020 & 50 & 430 & 380 & 1069 & n.d. & 254.5 & 55.4 & n.d. & 2.92 & 55.4 & 254.5 & n.d. & n.d. & n.d. & n.d. & n.d. & n.a. \\
\hline EXP-10A & Glyoxylic acid $+\mathrm{NH}_{4} \mathrm{Cl}(\mathrm{aq})+\mathrm{CO}(\mathrm{g})$ & 180 & 50 & 430 & 380 & 464 & n.d. & 259.0 & 55.0 & n.d. & 9.43 & n.a & 217.2 & 14.26 & 5 n.d. & 0.55 & n.d. & 0.3253 & 9.43 \\
\hline EXP-11A & $\mathrm{CO}+\mathrm{NH}_{3}(\mathrm{aq})$ & 60 & 50 & 430 & 380 & 2306 & n.d. & n.d. & 50.0 & n.d. & 9.93 & n.a & n.d. & 4.18 & 3 n.d. & 0.38 & n.d. & $-{ }^{c}$ & 8.31 \\
\hline & $\mathrm{CO}+\mathrm{NH}_{3}(\mathrm{aq})$ & 300 & 50 & 430 & 380 & 2148 & n.d. & n.d. & 50.0 & n.d. & 9.93 & n.a & 0.87 & 19.86 & 61.19 & 2.55 & n.d. & $-c$ & 5.91 \\
\hline & $\mathrm{CO}+\mathrm{NH}_{3}(\mathrm{aq})$ & 480 & 50 & 430 & 380 & 2434 & n.d. & n.d. & 50.0 & n.d. & 9.93 & n.a & 0.61 & 33.26 & 52.18 & 2.74 & n.d. & $-\mathrm{c}$ & 4.53 \\
\hline
\end{tabular}

c: detected but too little to be analyzed

Table 4. Results of UV experiments of $\mathrm{CO}_{2}$ and $\mathrm{CH}_{3} \mathrm{NH}_{2}$.

\begin{tabular}{|c|c|c|c|c|c|c|c|c|c|c|c|c|c|}
\hline \multirow{2}{*}{ Experiment } & \multicolumn{3}{|c|}{ Time solution Flask } & \multirow{2}{*}{$\begin{array}{l}\text { Gas } \\
{[\mathrm{ml}]}\end{array}$} & \multicolumn{4}{|c|}{ Initial species $[\mu \mathrm{mol}]$} & \multirow{2}{*}{ Initial $\mathrm{pH}$} & \multicolumn{3}{|c|}{ Final dissolved species $[\mu \mathrm{mol}]$} & \multirow{2}{*}{ Final $\mathrm{pH}$} \\
\hline & [min.] & [ml] & {$[\mathrm{ml}]$} & & $\mathrm{CO}_{2}$ & $\mathrm{CH}_{3} \mathrm{NH}_{2}$ & $\mathrm{NH}_{4}^{+}$ & Glycine & & $\mathrm{CH}_{3} \mathrm{NH}_{2}$ & $\mathrm{NH}_{4}^{+}$ & Glycine & \\
\hline EXP- $12 \mathrm{ACH}_{3} \mathrm{NH}_{2} \cdot \mathrm{HCl}(\mathrm{aq})+\mathrm{CO}_{2}(\mathrm{~g})$ & 60 & 50 & 430 & 380 & 1764 & 48.0 & n.d. & n.d. & 7.60 & 47.3 & 2.59 & 0.189 & 5.93 \\
\hline $\mathrm{CH}_{3} \mathrm{NH}_{2} \cdot \mathrm{HCl}(\mathrm{aq})+\mathrm{CO}_{2}(\mathrm{~g})$ & 180 & 50 & 430 & 380 & 1351 & 48.0 & n.d. & n.d. & 7.60 & 45.7 & 4.16 & 0.440 & 5.81 \\
\hline $\mathrm{CH}_{3} \mathrm{NH}_{2} \cdot \mathrm{HCl}(\mathrm{aq})+\mathrm{CO}_{2}(\mathrm{~g})$ & 420 & 50 & 430 & 380 & 1346 & 48.0 & n.d. & n.d. & 7.60 & 38.3 & 12.3 & 0.485 & n.a \\
\hline $\mathrm{CH}_{3} \mathrm{NH}_{2} \cdot \mathrm{HCl}(\mathrm{aq})+\mathrm{CO}_{2}(\mathrm{~g})$ & 720 & 50 & 430 & 380 & 1548 & 48.0 & n.d. & n.d. & 7.60 & 43.4 & 7.12 & 0.747 & 5.35 \\
\hline
\end{tabular}

n.a.: Not analyzed. 


\section{Appendix}

Photochemical synthesis of ammonia and amino acids from nitrous oxide Xiaofeng Zang ${ }^{1 *}$, Yuichiro Ueno ${ }^{1,2,3}$, Norio Kitadai ${ }^{2,3}$

Figure: chromatogram of amino acids.

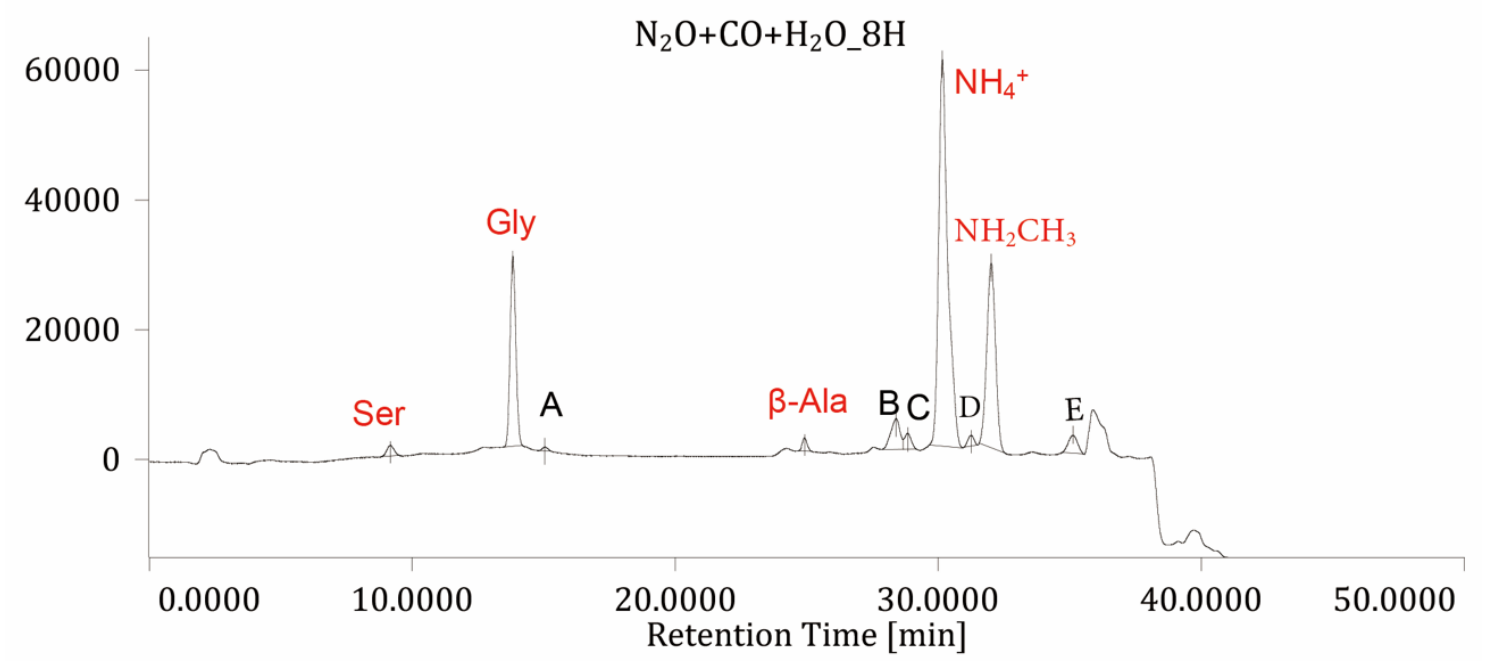

Table: List of chemical reactions used in our photochemical model.

\begin{tabular}{|l|l|l|l|}
\hline \multicolumn{1}{|c|}{ No } & $\begin{array}{c}\text { Rate } \\
\text { Constant }\end{array}$ & \multicolumn{1}{|c|}{ Reaction } & \multicolumn{1}{|c|}{ Reference } \\
\hline R1 & $3.15 \mathrm{E}-06$ & $\mathrm{H} 2 \mathrm{O}==>\mathrm{H}+\mathrm{OH}$ & Pavlov et al. 2001 \\
\hline R2 & $5.43 \mathrm{E}-08$ & $\mathrm{CO} 2==>\mathrm{CO}+\mathrm{O}$ & Pavlov et al. 2001 \\
\hline R3 & $5.95 \mathrm{E}-06$ & $\mathrm{CO} 2==>\mathrm{CO}+\mathrm{Od}$ & Pavlov et al. 2001 \\
\hline R4 & $1.01 \mathrm{E}-04$ & $\mathrm{O} 2==>\mathrm{O}+\mathrm{Od}$ & Pavlov et al. 2001 \\
\hline R5 & $1.93 \mathrm{E}-06$ & $\mathrm{O} 2==>\mathrm{O}+\mathrm{O}$ & Pavlov et al. 2001 \\
\hline R6 & $2.34 \mathrm{E}-01$ & $\mathrm{O} 3==>\mathrm{Od}+\mathrm{O} 2$ & Pavlov et al. 2001 \\
\hline R7 & $5.95 \mathrm{E}-02$ & $\mathrm{O} 3==>\mathrm{O}+\mathrm{O} 2$ & Pavlov et al. 2001 \\
\hline R8 & $2.20 \mathrm{E}-02$ & $\mathrm{HO} 2==>\mathrm{OH}+\mathrm{O}$ & Pavlov et al. 2001 \\
\hline R9 & $3.38 \mathrm{E}-03$ & $\mathrm{H} 2 \mathrm{O} 2==>\mathrm{OH}+\mathrm{OH}$ & Wen et al. 2001 \\
\hline R10 & $1.95 \mathrm{E}-03$ & $\mathrm{H} 2 \mathrm{CO}==>\mathrm{H} 2+\mathrm{CO}$ & Pavlov et al. 2001 \\
\hline R11 & $2.35 \mathrm{E}-03$ & $\mathrm{H} 2 \mathrm{CO}==>\mathrm{HCO}+\mathrm{H}$ & Pavlov et al. 2001 \\
\hline
\end{tabular}




\begin{tabular}{|c|c|c|c|}
\hline $\mathrm{R} 12$ & 4.02E-01 & $\mathrm{HCO}==>\mathrm{CO}+\mathrm{H}$ & Pinto et al. 1980 \\
\hline $\mathrm{R} 13$ & $1.00 \mathrm{E}-30$ & $\mathrm{HCOOH}==>\mathrm{OH}+\mathrm{HCO}$ & Pavlov et al. 2001 \\
\hline $\mathrm{R} 14$ & $4.88 \mathrm{E}-04$ & $\mathrm{CH} 3 \mathrm{OH}==>\mathrm{CH} 3+\mathrm{OH}$ & Wen et al.1989 \\
\hline $\mathrm{R} 15$ & $1.98 \mathrm{E}-03$ & $\mathrm{CH} 3 \mathrm{OH}==>\mathrm{H} 2 \mathrm{CO}+\mathrm{H} 2$ & Wen et al.1990 \\
\hline R16 & $1.98 \mathrm{E}-03$ & $\mathrm{CH} 3 \mathrm{OH}==>\mathrm{CH} 3 \mathrm{O}+\mathrm{H}$ & Wen et al.1991 \\
\hline $\mathrm{R} 17$ & $1.00 \mathrm{E}-30$ & $\mathrm{CH} 3 \mathrm{COOH}==>\mathrm{CH} 3 \mathrm{CO}+\mathrm{OH}$ & Wen et al.1992 \\
\hline $\mathrm{R} 18$ & $9.81 \mathrm{E}-03$ & $\mathrm{CH} 2 \mathrm{CO}==>\mathrm{H} 2 \mathrm{C}+\mathrm{CO}$ & Pavlov et al. 2001 \\
\hline R19 & $2.59 \mathrm{E}-03$ & $\mathrm{CH} 3 \mathrm{CHO}==>\mathrm{CH} 3+\mathrm{HCO}$ & Pavlov et al. 2001 \\
\hline $\mathrm{R} 20$ & $2.59 \mathrm{E}-03$ & $\mathrm{CH} 3 \mathrm{CHO}==>\mathrm{CH} 4+\mathrm{CO}$ & Pavlov et al. 2001 \\
\hline $\mathrm{R} 21$ & 5.19E-03 & $\mathrm{C} 2 \mathrm{H} 5 \mathrm{CHO}==>\mathrm{C} 2 \mathrm{H} 5+\mathrm{HCO}$ & Pavlov et al. 2001 \\
\hline $\mathrm{R} 22$ & $1.36 \mathrm{E}-03$ & $\mathrm{CH}==>\mathrm{C}+\mathrm{H}$ & Pavlov et al. 2001 \\
\hline $\mathrm{R} 23$ & $7.52 \mathrm{E}-03$ & $\mathrm{CH} 3==>\mathrm{HCH}+\mathrm{H}$ & Pavlov et al. 2001 \\
\hline $\mathrm{R} 24$ & $6.00 \mathrm{E}-34$ & $\mathrm{O}+\mathrm{O} 2+\mathrm{A}==>\mathrm{O} 3+\mathrm{A}$ & DeMore et al. 1997 \\
\hline $\mathrm{R} 25$ & $2.94 \mathrm{E}-33$ & $\mathrm{O}+\mathrm{O}+\mathrm{A}==>\mathrm{O} 2+\mathrm{A}$ & Javoy et al.2003 \\
\hline R26 & $8.34 \mathrm{E}-15$ & $\mathrm{O}+\mathrm{O} 3==>\mathrm{O} 2+\mathrm{O} 2$ & Atkinson et al. 2004 \\
\hline $\mathrm{R} 27$ & $2.94 \mathrm{E}-18$ & $\mathrm{O}+\mathrm{H} 2==>\mathrm{OH}+\mathrm{H}$ & Baulch et al.1992 \\
\hline $\mathrm{R} 28$ & $1.63 \mathrm{E}-21$ & $\mathrm{O}+\mathrm{H} 2 \mathrm{O}==>\mathrm{OH}+\mathrm{OH}$ & Lifshitz et al.1991 \\
\hline R29 & $2.20 \mathrm{E}-10$ & $\mathrm{Od}+\mathrm{H} 2 \mathrm{O}==>\mathrm{OH}+\mathrm{OH}$ & Dunlea et al.2004 \\
\hline $\mathrm{R} 30$ & $2.60 \mathrm{E}-11$ & $\mathrm{Od}+\mathrm{A}==>\mathrm{O}+\mathrm{A}$ & Sobral et al.1993 \\
\hline R31 & $4.04 \mathrm{E}-11$ & $\mathrm{Od}+\mathrm{O} 2==>\mathrm{O}+\mathrm{O} 2$ & DeMore et al. 1997 \\
\hline R32 & $1.00 \mathrm{E}-10$ & $\mathrm{Od}+\mathrm{H} 2==>\mathrm{OH}+\mathrm{H}$ & DeMore et al. 1997 \\
\hline R33 & $1.89 \mathrm{E}-12$ & $\mathrm{OH}+\mathrm{OH}==>\mathrm{H} 2 \mathrm{O}+\mathrm{O}$ & Atkinson et al. 2004 \\
\hline R34 & $6.97 \mathrm{E}-14$ & $\mathrm{OH}+\mathrm{O} 3==>\mathrm{HO} 2+\mathrm{O} 2$ & Atkinson et al. 2004 \\
\hline R35 & $3.25 \mathrm{E}-11$ & $\mathrm{OH}+\mathrm{O}==>\mathrm{H}+\mathrm{O} 2$ & Atkinson et al. 2004 \\
\hline R36 & $7.00 \mathrm{E}-15$ & $\mathrm{OH}+\mathrm{H} 2==>\mathrm{H} 2 \mathrm{O}+\mathrm{H}$ & Atkinson et al. 2004 \\
\hline $\mathrm{R} 37$ & $6.78 \mathrm{E}-31$ & $\mathrm{H}+\mathrm{OH}+\mathrm{A}==>\mathrm{H} 2 \mathrm{O}+\mathrm{A}$ & Baulch et al. 1992 \\
\hline R38 & $5.50 \mathrm{E}-32$ & $\mathrm{H}+\mathrm{O} 2+\mathrm{A}==>\mathrm{HO} 2+\mathrm{A}$ & Atkinson et al. 2004 \\
\hline R39 & $2.92 \mathrm{E}-11$ & $\mathrm{H}+\mathrm{O} 3==>\mathrm{OH}+\mathrm{O} 2$ & DeMore et al. 1997 \\
\hline $\mathrm{R} 40$ & $6.48 \mathrm{E}-12$ & $\mathrm{H}+\mathrm{HO} 2==>\mathrm{H} 2+\mathrm{O} 2$ & Atkinson et al. 2004 \\
\hline $\mathrm{R} 41$ & $1.62 \mathrm{E}-12$ & $\mathrm{H}+\mathrm{HO} 2==>\mathrm{H} 2 \mathrm{O}+\mathrm{O}$ & Atkinson et al. 2004 \\
\hline $\mathrm{R} 42$ & $7.29 \mathrm{E}-11$ & $\mathrm{H}+\mathrm{HO} 2==>\mathrm{OH}+\mathrm{OH}$ & Atkinson et al. 2004 \\
\hline $\mathrm{R} 43$ & $3.00 \mathrm{E}-25$ & $\mathrm{H}+\mathrm{H} 2 \mathrm{O}==>\mathrm{OH}+\mathrm{H} 2$ & Baulch et al.1992 \\
\hline
\end{tabular}




\begin{tabular}{|c|c|c|c|}
\hline $\mathrm{R} 44$ & 8.89E-33 & $\mathrm{H}+\mathrm{H}+\mathrm{A}==>\mathrm{H} 2+\mathrm{A}$ & Baulch et al.1992 \\
\hline $\mathrm{R} 45$ & $5.84 \mathrm{E}-11$ & $\mathrm{HO} 2+\mathrm{O}==>\mathrm{OH}+\mathrm{O} 2$ & Atkinson et al. 2004 \\
\hline $\mathrm{R} 46$ & $2.15 \mathrm{E}-15$ & $\mathrm{HO} 2+\mathrm{O} 3==>\mathrm{OH}+\mathrm{O} 2+\mathrm{O} 2$ & Atkinson et al. 2004 \\
\hline $\mathrm{R} 47$ & $1.64 \mathrm{E}-12$ & $\mathrm{HO} 2+\mathrm{HO} 2==>\mathrm{H} 2 \mathrm{O} 2+\mathrm{O} 2$ & DeMore et al. 1997 \\
\hline $\mathrm{R} 48$ & $1.78 \mathrm{E}-15$ & $\mathrm{H} 2 \mathrm{O} 2+\mathrm{O}==>\mathrm{OH}+\mathrm{HO} 2$ & Atkinson et al. 2004 \\
\hline $\mathrm{R} 49$ & $1.70 \mathrm{E}-12$ & $\mathrm{H} 2 \mathrm{O} 2+\mathrm{OH}==>\mathrm{HO} 2+\mathrm{H} 2 \mathrm{O}$ & Atkinson et al. 2004 \\
\hline $\mathrm{R} 50$ & $4.18 \mathrm{E}-14$ & $\mathrm{H} 2 \mathrm{O} 2+\mathrm{H}==>\mathrm{OH}+\mathrm{H} 2 \mathrm{O}$ & Baulch et al.1992 \\
\hline $\mathrm{R} 51$ & $1.50 \mathrm{E}-13$ & $\mathrm{CO}+\mathrm{OH}==>\mathrm{CO} 2+\mathrm{H}$ & Baulch et al.1992 \\
\hline $\mathrm{R} 52$ & $4.54 \mathrm{E}-36$ & $\mathrm{CO}+\mathrm{O}+\mathrm{A}==\mathrm{CO} 2+\mathrm{A}$ & Tsang et al. 1986 \\
\hline $\mathrm{R} 53$ & $1.18 \mathrm{E}-34$ & $\mathrm{CO}+\mathrm{H}+\mathrm{A}==>\mathrm{HCO}+\mathrm{A}$ & Baulch et al.1994 \\
\hline R54 & $1.00 \mathrm{E}-10$ & $\mathrm{HCO}+\mathrm{O}==>\mathrm{H}+\mathrm{CO} 2$ & Baulch et al.1992 \\
\hline R55 & $1.00 \mathrm{E}-10$ & $\mathrm{HCO}+\mathrm{O}==>\mathrm{OH}+\mathrm{CO}$ & Baulch et al.1992 \\
\hline $\mathrm{R} 56$ & $5.62 \mathrm{E}-12$ & $\mathrm{HCO}+\mathrm{O} 2==>\mathrm{HO} 2+\mathrm{CO}$ & Atkinson et al. 2004 \\
\hline $\mathrm{R} 57$ & $1.20 \mathrm{E}-10$ & $\mathrm{HCO}+\mathrm{H}==>\mathrm{H} 2+\mathrm{CO}$ & Pavlov et al. 2001 \\
\hline $\mathrm{R} 58$ & $2.48 \mathrm{E}-21$ & $\mathrm{HCO}+\mathrm{H} 2==>\mathrm{H} 2 \mathrm{CO}+\mathrm{H}$ & Tsang et al.1986 \\
\hline R59 & $5.00 \mathrm{E}-11$ & $\mathrm{HCO}+\mathrm{OH}==>\mathrm{H} 2 \mathrm{O}+\mathrm{CO}$ & Baulch et al.1992 \\
\hline R60 & $3.99 \mathrm{E}-22$ & $\mathrm{HCO}+\mathrm{A}==>\mathrm{CO}+\mathrm{H}+\mathrm{A}$ & Friedrichs et al.2002 \\
\hline R61 & $3.00 \mathrm{E}-11$ & $\mathrm{HCO}+\mathrm{HCO}==>\mathrm{H} 2 \mathrm{CO}+\mathrm{CO}$ & Baulch et al.1992 \\
\hline R62 & $1.64 \mathrm{E}-13$ & $\mathrm{H} 2 \mathrm{CO}+\mathrm{O}==>\mathrm{HCO}+\mathrm{OH}$ & Baulch et al.1992 \\
\hline R63 & $8.34 \mathrm{E}-12$ & $\mathrm{H} 2 \mathrm{CO}+\mathrm{OH}==>\mathrm{H} 2 \mathrm{O}+\mathrm{HCO}$ & Atkinson et al. 2004 \\
\hline R64 & $2.15 \mathrm{E}-13$ & $\mathrm{H} 2 \mathrm{CO}+\mathrm{OH}==>\mathrm{HCOOH}+\mathrm{H}$ & Yetter et al. 1989 \\
\hline R65 & $3.84 \mathrm{E}-15$ & $\mathrm{H} 2 \mathrm{CO}+\mathrm{H}==>\mathrm{H} 2+\mathrm{HCO}$ & Baulch et al.1994 \\
\hline R66 & $3.00 \mathrm{E}-16$ & $\mathrm{H} 2 \mathrm{CO}+\mathrm{H}==>\mathrm{CH} 3 \mathrm{O}$ & Curran et al. 2006 \\
\hline R67 & $1.00 \mathrm{E}-17$ & $\mathrm{H} 2 \mathrm{CO}+\mathrm{HCO}==>\mathrm{CH} 3 \mathrm{O}+\mathrm{CO}$ & Wen et al. 1989 \\
\hline R68 & $3.00 \mathrm{E}-11$ & $\mathrm{CH} 3 \mathrm{O}+\mathrm{OH}==>\mathrm{H} 2 \mathrm{CO}+\mathrm{H} 2 \mathrm{O}$ & Tsang et al. 1986 \\
\hline R69 & $3.30 \mathrm{E}-11$ & $\mathrm{CH} 3 \mathrm{O}+\mathrm{H}==>\mathrm{H} 2 \mathrm{CO}+\mathrm{H} 2$ & Baulch et al.1994 \\
\hline $\mathrm{R} 70$ & $1.50 \mathrm{E}-10$ & $\mathrm{CH} 3 \mathrm{O}+\mathrm{HCO}==>\mathrm{CH} 3 \mathrm{OH}+\mathrm{CO}$ & Tsang et al. 1986 \\
\hline R71 & $1.15 \mathrm{E}-15$ & $\mathrm{CH} 3 \mathrm{O}+\mathrm{H} 2 \mathrm{CO}==>\mathrm{CH} 3 \mathrm{OH}+\mathrm{HCO}$ & Tsang et al. 1986 \\
\hline $\mathrm{R} 72$ & $3.57 \mathrm{E}-09$ & $\mathrm{CH} 3 \mathrm{O}+\mathrm{H} 2==>\mathrm{CH} 3 \mathrm{OH}+\mathrm{H}$ & Jodkowski et al. 1999 \\
\hline $\mathrm{R} 73$ & $5.04 \mathrm{E}-07$ & $\mathrm{CH} 3 \mathrm{O}+\mathrm{CH} 4==>\mathrm{CH} 3 \mathrm{OH}+\mathrm{CH} 3$ & Tsang et al. 1986 \\
\hline R74 & $6.55 \mathrm{E}-20$ & $\mathrm{CH} 3 \mathrm{O}+\mathrm{CO}==>\mathrm{CH} 3+\mathrm{CO} 2$ & Tsang et al. 1986 \\
\hline $\mathrm{R} 75$ & $1.27 \mathrm{E}-15$ & $\mathrm{CH} 3 \mathrm{OH}+\mathrm{H}==>\mathrm{CH} 3 \mathrm{O}+\mathrm{H} 2$ & Warnatz ,1984 \\
\hline
\end{tabular}




\begin{tabular}{|c|c|c|c|}
\hline $\mathrm{R} 76$ & $6.16 \mathrm{E}-13$ & $\mathrm{CH} 3 \mathrm{OH}+\mathrm{OH}==>\mathrm{CH} 3 \mathrm{O}+\mathrm{H} 2 \mathrm{O}$ & Warnatz ,1984 \\
\hline $\mathrm{R} 77$ & $6.70 \mathrm{E}-12$ & $\mathrm{CH} 3+\mathrm{OH}==>\mathrm{CO}+\mathrm{H} 2+\mathrm{H} 2$ & Fenimore et al.,1968 \\
\hline R78 & $4.43 \mathrm{E}-13$ & $\mathrm{CH} 3+\mathrm{OH}==>\mathrm{CH} 3 \mathrm{O}+\mathrm{H}$ & Jasper et al.,2007 \\
\hline R79 & $1.10 \mathrm{E}-10$ & $\mathrm{CH} 3+\mathrm{O}==>\mathrm{H} 2 \mathrm{CO}+\mathrm{H}$ & Baulch et al.1992 \\
\hline $\mathrm{R} 80$ & $4.00 \mathrm{E}-31$ & $\mathrm{CH} 3+\mathrm{O} 2==>\mathrm{H} 2 \mathrm{CO}+\mathrm{OH}$ & Tsang et al. 1986 \\
\hline $\mathrm{R} 81$ & $2.59 \mathrm{E}-12$ & $\mathrm{CH} 3+\mathrm{O} 3==>\mathrm{H} 2 \mathrm{CO}+\mathrm{HO} 2$ & DeMore et al. 1992 \\
\hline R82 & $6.36 \mathrm{E}-37$ & $\mathrm{CH} 3+\mathrm{CO}+\mathrm{A}==>\mathrm{CH} 3 \mathrm{CO}+\mathrm{A}$ & Baulch et al.1994 \\
\hline $\mathrm{R} 83$ & $5.93 \mathrm{E}-28$ & $\mathrm{CH} 3+\mathrm{H}+\mathrm{A}==>\mathrm{CH} 4+\mathrm{A}$ & Baulch et al.1994 \\
\hline $\mathrm{R} 84$ & $1.66 \mathrm{E}-16$ & $\mathrm{CH} 3+\mathrm{H} 2 \mathrm{CO}==>\mathrm{CH} 4+\mathrm{HCO}$ & Baulch et al.1994 \\
\hline $\mathrm{R} 85$ & $2.01 \mathrm{E}-10$ & $\mathrm{CH} 3+\mathrm{HCO}==>\mathrm{CH} 4+\mathrm{CO}$ & Tsang et al. 1986 \\
\hline R86 & $5.78 \mathrm{E}-14$ & $\mathrm{CH} 3+\mathrm{H} 2==>\mathrm{CH} 4+\mathrm{H}$ & Baulch et al.1992 \\
\hline $\mathrm{R} 87$ & $3.00 \mathrm{E}-11$ & $\mathrm{CH} 3+\mathrm{HCO}==>\mathrm{CH} 3 \mathrm{CHO}$ & Tsang et al. 1986 \\
\hline $\mathrm{R} 88$ & $2.20 \mathrm{E}-26$ & $\mathrm{CH} 3+\mathrm{CH} 3+\mathrm{A}==>\mathrm{C} 2 \mathrm{H} 6+\mathrm{A}$ & Baulch et al.1992 \\
\hline R89 & $5.00 \mathrm{E}-11$ & $\mathrm{CH} 3 \mathrm{CO}+\mathrm{O}==>\mathrm{H} 2 \mathrm{CO}+\mathrm{HCO}$ & Zhnle, 1986 \\
\hline R90 & $1.10 \mathrm{E}-13$ & $\mathrm{CH} 3 \mathrm{CO}+\mathrm{H}==>\mathrm{CH} 3+\mathrm{HCO}$ & Ohmori et al. 1989 \\
\hline R91 & $5.92 \mathrm{E}-14$ & $\mathrm{CH} 3 \mathrm{CO}+\mathrm{H}==>\mathrm{CH} 2 \mathrm{CO}+\mathrm{H} 2$ & Ohmori et al. 1989 \\
\hline R92 & $5.40 \mathrm{E}-11$ & $\mathrm{CH} 3 \mathrm{CO}+\mathrm{CH} 3==>\mathrm{C} 2 \mathrm{H} 6+\mathrm{CO}$ & Adachi et al. 1981 \\
\hline R93 & $8.60 \mathrm{E}-11$ & $\mathrm{CH} 3 \mathrm{CO}+\mathrm{CH} 3==>\mathrm{CH} 4+\mathrm{CH} 2 \mathrm{CO}$ & Adachi et al. 1981 \\
\hline R94 & $4.50 \mathrm{E}-11$ & $\mathrm{CH} 3 \mathrm{CO}+\mathrm{HCO}==>\mathrm{CH} 3 \mathrm{CHO}+\mathrm{CO}$ & Tsang et al. 1986 \\
\hline R95 & $6.05 \mathrm{E}-14$ & $\mathrm{CH} 2 \mathrm{CO}+\mathrm{H}==>\mathrm{CH} 3+\mathrm{CO}$ & Senosiain et al.2006 \\
\hline R96 & $3.30 \mathrm{E}-13$ & $\mathrm{CH} 2 \mathrm{CO}+\mathrm{O}==>\mathrm{H} 2 \mathrm{CO}+\mathrm{CO}$ & Miller et al.1982 \\
\hline R97 & $2.23 \mathrm{E}-13$ & $\begin{array}{l}\mathrm{CH} 3 \mathrm{CHO}+\mathrm{CH} 3==>\mathrm{CH} 3 \mathrm{CO}+\mathrm{CH} \\
4\end{array}$ & Baulch et al.1992 \\
\hline R98 & $2.23 \mathrm{E}-13$ & $\mathrm{CH} 3 \mathrm{CHO}+\mathrm{H}==>\mathrm{CH} 3 \mathrm{CO}+\mathrm{H} 2$ & Ohmori et al. 1989 \\
\hline R99 & $5.80 \mathrm{E}-13$ & $\mathrm{CH} 3 \mathrm{CHO}+\mathrm{O}==>\mathrm{CH} 3 \mathrm{CO}+\mathrm{OH}$ & DeMore et al. 1997 \\
\hline $\mathrm{R} 100$ & $1.59 \mathrm{E}-11$ & $\mathrm{CH} 3 \mathrm{CHO}+\mathrm{OH}==>\mathrm{CH} 3 \mathrm{CO}+\mathrm{H} 2 \mathrm{O}$ & Atkinson et al.2001 \\
\hline R101 & $5.16 \mathrm{E}-13$ & $\mathrm{CH} 3 \mathrm{CHO}+\mathrm{OH}==>\mathrm{HCOOH}+\mathrm{CH} 3$ & Cameron et al.2002 \\
\hline $\mathrm{R} 102$ & $3.44 \mathrm{E}-13$ & $\mathrm{CH} 3 \mathrm{CHO}+\mathrm{OH}==>\mathrm{CH} 3 \mathrm{COOH}+\mathrm{H}$ & Cameron et al.2002 \\
\hline $\mathrm{R} 103$ & $2.82 \mathrm{E}-13$ & $\mathrm{HCOOH}+\mathrm{OH}==>\mathrm{H} 2 \mathrm{O}+\mathrm{CO} 2+\mathrm{H}$ & Wine et al. 1985 \\
\hline R104 & $4.76 \mathrm{E}-18$ & $\mathrm{CH} 4+\mathrm{O}==>\mathrm{CH} 3+\mathrm{OH}$ & Miyoshi et al. 1993 \\
\hline R105 & $1.28 \mathrm{E}-10$ & $\mathrm{CH} 4+\mathrm{Od}==>\mathrm{CH} 3+\mathrm{OH}$ & DeMore et al. 1994 \\
\hline R106 & $2.25 \mathrm{E}-11$ & $\mathrm{CH} 4+\mathrm{Od}==>\mathrm{H} 2 \mathrm{CO}+\mathrm{H} 2$ & DeMore et al. 1994 \\
\hline
\end{tabular}




\begin{tabular}{|c|c|c|c|}
\hline R107 & $6.60 \mathrm{E}-15$ & $\mathrm{CH} 4+\mathrm{OH}==>\mathrm{CH} 3+\mathrm{H} 2 \mathrm{O}$ & Srinivasan et al. 2005 \\
\hline R108 & 4.87E-10 & $\mathrm{CH}+\mathrm{CH} 4==>\mathrm{C} 2 \mathrm{H} 4+\mathrm{H}$ & Cyzewski et al. 2002 \\
\hline R109 & $1.84 \mathrm{E}-12$ & $\mathrm{CH}+\mathrm{CO} 2==>\mathrm{HCO}+\mathrm{CO}$ & Beman et al. 1982 \\
\hline $\mathrm{R} 110$ & $1.40 \mathrm{E}-11$ & $\mathrm{CH}+\mathrm{H}==>\mathrm{C}+\mathrm{H} 2$ & Grebe et al. 1982 \\
\hline R111 & $5.02 \mathrm{E}-30$ & $\mathrm{CH}+\mathrm{H} 2+\mathrm{A}==>\mathrm{CH} 3+\mathrm{A}$ & Fulle et al. 1997 \\
\hline $\mathrm{R} 112$ & $9.50 \mathrm{E}-11$ & $\mathrm{CH}+\mathrm{O}==>\mathrm{CO}+\mathrm{H}$ & Baulch et al.1992 \\
\hline $\mathrm{R} 113$ & $5.90 \mathrm{E}-11$ & $\mathrm{CH}+\mathrm{O} 2==>\mathrm{CO}+\mathrm{OH}$ & Lichtin et al. 1984 \\
\hline R114 & $3.49 \mathrm{E}-19$ & $\mathrm{HCH}+\mathrm{CH} 4==>\mathrm{CH} 3+\mathrm{CH} 3$ & Bohland et al. 1985 \\
\hline R115 & $1.00 \mathrm{E}-12$ & $\mathrm{HCH}+\mathrm{CO} 2==>\mathrm{H} 2 \mathrm{CO}+\mathrm{CO}$ & Tsang et al. 1986 \\
\hline R116 & $1.26 \mathrm{E}-11$ & $\mathrm{HCH}+\mathrm{H} 2==>\mathrm{H} 2 \mathrm{C}+\mathrm{H} 2$ & Romani et al. 1993 \\
\hline R117 & $5.00 \mathrm{E}-15$ & $\mathrm{HCH}+\mathrm{H} 2==>\mathrm{CH} 3+\mathrm{H}$ & Tsang et al. 1986 \\
\hline $\mathrm{R} 118$ & $8.80 \mathrm{E}-12$ & $\mathrm{HCH}+\mathrm{A}==>\mathrm{H} 2 \mathrm{C}+\mathrm{A}$ & Ashfold et al. 1981 \\
\hline R119 & $3.00 \mathrm{E}-11$ & $\mathrm{HCH}+\mathrm{O} 2==>\mathrm{HCO}+\mathrm{OH}$ & Ashfold et al. 1981 \\
\hline $\mathrm{R} 120$ & $1.66 \mathrm{E}-18$ & $\mathrm{HCH}+\mathrm{OH}==>\mathrm{CH}+\mathrm{H} 2 \mathrm{O}$ & Jasper et al. 2007 \\
\hline $\mathrm{R} 121$ & $1.25 \mathrm{E}-10$ & $\mathrm{HCH}+\mathrm{OH}==>\mathrm{CH} 2 \mathrm{O}+\mathrm{H}$ & Jasper et al. 2007 \\
\hline $\mathrm{R} 122$ & $3.00 \mathrm{E}-11$ & $\mathrm{H} 2 \mathrm{C}+\mathrm{C} 2 \mathrm{H} 3==>\mathrm{CH} 3+\mathrm{C} 2 \mathrm{H} 2$ & Tsang et al. 1986 \\
\hline R123 & $3.00 \mathrm{E}-11$ & $\mathrm{H} 2 \mathrm{C}+\mathrm{C} 2 \mathrm{H} 5==>\mathrm{CH} 3+\mathrm{C} 2 \mathrm{H} 4$ & Tsang et al. 1986 \\
\hline $\mathrm{R} 124$ & $7.00 \mathrm{E}-11$ & $\mathrm{H} 2 \mathrm{C}+\mathrm{CH} 3==>\mathrm{C} 2 \mathrm{H} 4+\mathrm{H}$ & Tsang et al. 1986 \\
\hline $\mathrm{R} 125$ & $1.00 \mathrm{E}-28$ & $\mathrm{H} 2 \mathrm{C}+\mathrm{CO}+\mathrm{A}==>\mathrm{CH} 2 \mathrm{CO}+\mathrm{A}$ & Yung et al. 1988 \\
\hline $\mathrm{R} 126$ & $3.90 \mathrm{E}-14$ & $\mathrm{H} 2 \mathrm{C}+\mathrm{CO} 2==>\mathrm{H} 2 \mathrm{CO}+\mathrm{CO}$ & Tsang et al. 1986 \\
\hline R127 & $1.37 \mathrm{E}-10$ & $\mathrm{H} 2 \mathrm{C}+\mathrm{H}==>\mathrm{CH}+\mathrm{H} 2$ & Baulch et al. 1992 \\
\hline $\mathrm{R} 128$ & $1.42 \mathrm{E}-29$ & $\mathrm{H} 2 \mathrm{C}+\mathrm{H}+\mathrm{A}==>\mathrm{CH} 3+\mathrm{A}$ & Gladstone et al. 1996 \\
\hline R129 & $2.00 \mathrm{E}-10$ & $\mathrm{H} 2 \mathrm{C}+\mathrm{O}==>\mathrm{CO}+\mathrm{H}+\mathrm{H}$ & Baulch at al. 1994 \\
\hline $\mathrm{R} 130$ & $8.00 \mathrm{E}-12$ & $\mathrm{H} 2 \mathrm{C}+\mathrm{O}=>\mathrm{CH}+\mathrm{OH}$ & Huebner et al. 1980 \\
\hline $\mathrm{R} 131$ & $8.30 \mathrm{E}-11$ & $\mathrm{H} 2 \mathrm{C}+\mathrm{O}==>\mathrm{CO}+\mathrm{H} 2$ & Baulch at al. 1994 \\
\hline $\mathrm{R} 132$ & $1.00 \mathrm{E}-11$ & $\mathrm{H} 2 \mathrm{C}+\mathrm{O}==>\mathrm{HCO}+\mathrm{H}$ & Huebner et al. 1980 \\
\hline $\mathrm{R} 133$ & $3.37 \mathrm{E}-12$ & $\mathrm{H} 2 \mathrm{C}+\mathrm{O} 2==>\mathrm{HCO}+\mathrm{OH}$ & Baulch et al. 1994 \\
\hline $\mathrm{R} 134$ & $1.01 \mathrm{E}-11$ & $\mathrm{CH} 2 \mathrm{O}+\mathrm{OH}==>\mathrm{H} 2 \mathrm{O}+\mathrm{HCO}$ & Baulch at al. 1994 \\
\hline $\mathrm{R} 135$ & $1.73 \mathrm{E}-13$ & $\mathrm{CH} 2 \mathrm{O}+\mathrm{O}==>\mathrm{OH}+\mathrm{HCO}$ & Baulch at al. 1994 \\
\hline $\mathrm{R} 136$ & $5.71 \mathrm{E}-14$ & $\mathrm{CH} 2 \mathrm{O}+\mathrm{H}==>\mathrm{H} 2+\mathrm{HCO}$ & Baulch at al. 1994 \\
\hline $\mathrm{R} 137$ & $3.33 \mathrm{E}-05$ & $\mathrm{~N} 2 \mathrm{O}==>\mathrm{N} 2+\mathrm{Od}$ & Pavlov et al. 2001 \\
\hline R138 & 7.40E-05 & $\mathrm{NO}==>\mathrm{N}+\mathrm{O}$ & Pavlov et al. 2001 \\
\hline
\end{tabular}




\begin{tabular}{|c|c|c|c|}
\hline R139 & $2.34 \mathrm{E}-01$ & $\mathrm{NO} 2==>\mathrm{NO}+\mathrm{O}$ & Pavlov et al. 2001 \\
\hline R140 & $6.84 \mathrm{E}-02$ & $\mathrm{HNO} 2==>\mathrm{NO}+\mathrm{OH}$ & Pavlov et al. 2001 \\
\hline R141 & 4.62E-03 & $\mathrm{HNO} 3==>\mathrm{NO} 2+\mathrm{OH}$ & Pavlov et al. 2001 \\
\hline $\mathrm{R} 142$ & $6.84 \mathrm{E}-02$ & $\mathrm{HNO}==>\mathrm{NO}+\mathrm{H}$ & Pavlov et al. 2001 \\
\hline $\mathrm{R} 143$ & $1.00 \mathrm{E}-30$ & $\mathrm{NH} 3==>\mathrm{NH} 2+\mathrm{H}$ & Pavlov et al. 2001 \\
\hline R144 & $3.33 \mathrm{E}-03$ & $\mathrm{NH}==>\mathrm{N}+\mathrm{H}$ & Pavlov et al. 2001 \\
\hline R145 & $3.33 \mathrm{E}-03$ & $\mathrm{NH} 2==>\mathrm{NH}+\mathrm{H}$ & Pavlov et al. 2001 \\
\hline R146 & $1.53 \mathrm{E}-01$ & $\mathrm{NH} 2==>\mathrm{NHH}$ & Pavlov et al. 2001 \\
\hline R147 & $6.71 \mathrm{E}-11$ & $\mathrm{~N} 2 \mathrm{O}+\mathrm{Od}==>\mathrm{NO}+\mathrm{NO}$ & DeMore et al., 1997 \\
\hline R148 & $4.90 \mathrm{E}-11$ & $\mathrm{~N} 2 \mathrm{O}+\mathrm{Od}==>\mathrm{N} 2+\mathrm{O} 2$ & DeMore et al., 1997 \\
\hline R149 & $4.94 \mathrm{E}-34$ & $\mathrm{~N} 2 \mathrm{O}+\mathrm{H}==>\mathrm{NO}+\mathrm{NH}$ & Bozzelli et al. 1994 \\
\hline $\mathrm{R} 150$ & $4.31 \mathrm{E}-18$ & $\mathrm{~N} 2 \mathrm{O}+\mathrm{H}==>\mathrm{OH}+\mathrm{N} 2$ & Arthru et al. 1997 \\
\hline R151 & $1.49 \mathrm{E}-17$ & $\mathrm{~N} 2 \mathrm{O}+\mathrm{H}==>\mathrm{HNNO}$ & Diar et al. 1995 \\
\hline $\mathrm{R} 152$ & 8.02E-19 & $\mathrm{N} 2 \mathrm{O}+\mathrm{OH}==>\mathrm{HO} 2+\mathrm{N} 2$ & Tsang et al. 1991 \\
\hline $\mathrm{R} 153$ & $6.88 \mathrm{E}-31$ & $\mathrm{NO}+\mathrm{OH}+\mathrm{A}==>\mathrm{HNO} 2+\mathrm{A}$ & DeMore et al. 1997 \\
\hline $\mathrm{R} 154$ & $3.86 \mathrm{E}-32$ & $\mathrm{NO}+\mathrm{H}+\mathrm{A}==\mathrm{HNO}+\mathrm{A}$ & Tsang et al. 1991 \\
\hline $\mathrm{R} 155$ & $8.93 \mathrm{E}-32$ & $\mathrm{NO}+\mathrm{O}+\mathrm{A}==>\mathrm{NO} 2+\mathrm{A}$ & DeMore et al. 1997 \\
\hline R156 & $5.80 \mathrm{E}-15$ & $\mathrm{NO}+\mathrm{Od}==>\mathrm{O} 2+\mathrm{N}$ & Blais 1985 (upper limit) \\
\hline $\mathrm{R} 157$ & $8.84 \mathrm{E}-12$ & $\mathrm{NO}+\mathrm{HO} 2==>\mathrm{NO} 2+\mathrm{OH}$ & Atkinson et al. 2004 \\
\hline $\mathrm{R} 158$ & $1.35 \mathrm{E}-11$ & $\mathrm{NO}+\mathrm{HCO}==>\mathrm{CO}+\mathrm{HNO}$ & Dammeier et al., 2007 \\
\hline R159 & $1.18 \mathrm{E}-29$ & $\mathrm{NO}+\mathrm{CH} 3+\mathrm{A}==>\mathrm{CH} 3 \mathrm{NO}+\mathrm{A}$ & Jodkowski et al., 1993 \\
\hline R160 & $3.65 \mathrm{E}-12$ & $\mathrm{NO}+\mathrm{HCH}==>\mathrm{HCN}+\mathrm{OH}$ & Fikri et al., 2001 \\
\hline R161 & $3.65 \mathrm{E}-11$ & $\mathrm{NO}+\mathrm{HCH}==>\mathrm{H}+\mathrm{HCNO}$ & Fikri et al., 2001 \\
\hline R162 & $1.37 \mathrm{E}-10$ & $\mathrm{NO}+\mathrm{CH}==>\mathrm{O}+\mathrm{HCN}$ & Bergeat et a 1., 1998 \\
\hline R163 & $3.99 \mathrm{E}-11$ & $\mathrm{NO}+\mathrm{CH}==>\mathrm{H}+\mathrm{NCO}$ & Bergeat et a 1., 1998 \\
\hline R164 & $1.33 \mathrm{E}-11$ & $\mathrm{NO}+\mathrm{CH}==>\mathrm{HCO}+\mathrm{N}$ & Bergeat et a 1., 1998 \\
\hline R165 & $2.00 \mathrm{E}-10$ & $\mathrm{NO}+\mathrm{CH}==>\mathrm{CO}+\mathrm{NH}$ & Geiger et al., 1999 \\
\hline R166 & $1.40 \mathrm{E}-10$ & $\mathrm{NO}+\mathrm{CH}==>\mathrm{OH}+\mathrm{CN}$ & Geiger et al., 1999 \\
\hline R167 & $1.54 \mathrm{E}-11$ & $\mathrm{NO}+\mathrm{NCO}==>\mathrm{CO}+\mathrm{N} 2 \mathrm{O}$ & Lin et al. 1993 \\
\hline R168 & $1.96 \mathrm{E}-11$ & $\mathrm{NO}+\mathrm{NCO}==>\mathrm{CO} 2+\mathrm{N} 2$ & Lin et al. 1993 \\
\hline R169 & $2.16 \mathrm{E}-15$ & $\mathrm{NH}+\mathrm{NH}==>\mathrm{NH} 2+\mathrm{N}$ & Klippenstein et al. 2009 \\
\hline
\end{tabular}




\begin{tabular}{|c|c|c|c|}
\hline $\mathrm{R} 170$ & $1.44 \mathrm{E}-28$ & $\mathrm{NH}+\mathrm{NH}+\mathrm{A}==>\mathrm{HNNH}+\mathrm{A}$ & Nicholas et al. 1986 \\
\hline $\mathrm{R} 171$ & $1.16 \mathrm{E}-09$ & $\mathrm{NH}+\mathrm{NH}==>\mathrm{N} 2+\mathrm{H}+\mathrm{H}$ & Meaburn et al. 1968 \\
\hline R172 & $3.67 \mathrm{E}-19$ & $\mathrm{NH}+\mathrm{NO}==>\mathrm{O}+\mathrm{HNN}$ & Bozzelli et al. 1994 \\
\hline R173 & $2.87 \mathrm{E}-11$ & $\mathrm{NH}+\mathrm{NO}==>\mathrm{N} 2 \mathrm{O}+\mathrm{H}$ & Bozzelli et al. 1994 \\
\hline R174 & $4.78 \mathrm{E}-12$ & $\mathrm{NH}+\mathrm{NO}==>\mathrm{OH}+\mathrm{N} 2$ & Bozzelli et al. 1994 \\
\hline R175 & $1.17 \mathrm{E}-20$ & $\mathrm{NH}+\mathrm{OH}==>\mathrm{NH} 2+\mathrm{O}$ & Cohen et al. 1991 \\
\hline R176 & $6.81 \mathrm{E}-11$ & $\mathrm{NH}+\mathrm{OH}==>\mathrm{H}+\mathrm{HNO}$ & Klippenstein et al. 2009 \\
\hline R177 & $1.39 \mathrm{E}-12$ & $\mathrm{NH}+\mathrm{OH}==>\mathrm{H} 2 \mathrm{O}+\mathrm{N}$ & Klippenstein et al. 2009 \\
\hline R178 & $1.89 \mathrm{E}-11$ & $\mathrm{NH}+\mathrm{N}==>\mathrm{N} 2+\mathrm{H}$ & Caridade et al. 2005 \\
\hline R179 & $1.16 \mathrm{E}-10$ & $\mathrm{NH}+\mathrm{O}==>\mathrm{NO}+\mathrm{H}$ & Cohen et al. 1991 \\
\hline $\mathrm{R} 180$ & $1.16 \mathrm{E}-11$ & $\mathrm{NH}+\mathrm{O}==>\mathrm{OH}+\mathrm{N}$ & Cohen et al. 1991 \\
\hline R181 & $2.11 \mathrm{E}-24$ & $\mathrm{NH}+\mathrm{CH} 4==>\mathrm{CH} 3+\mathrm{NH} 2$ & Xu et al. 1999 \\
\hline R182 & $1.25 \mathrm{E}-32$ & $\mathrm{~N}+\mathrm{N}+\mathrm{A}==>\mathrm{N} 2+\mathrm{A}$ & Knipovich et al. 1988 \\
\hline $\mathrm{R} 183$ & $9.16 \mathrm{E}-33$ & $\mathrm{~N}+\mathrm{O}+\mathrm{A}==>\mathrm{NO}+\mathrm{A}$ & Campbell et al. 1973 \\
\hline $\mathrm{R} 184$ & $1.89 \mathrm{E}-11$ & $\mathrm{~N}+\mathrm{NH}==>\mathrm{N} 2+\mathrm{H}$ & Caridade et al. 2005 \\
\hline $\mathrm{R} 185$ & $5.02 \mathrm{E}-32$ & $\mathrm{~N}+\mathrm{H}+\mathrm{A}==>\mathrm{NH}+\mathrm{A}$ & Brown et al. 1973 \\
\hline R186 & 2.92E-11 & $\mathrm{N}+\mathrm{NO}==>\mathrm{N} 2+\mathrm{O}$ & DeMore et al. 1997 \\
\hline $\mathrm{R} 187$ & $4.70 \mathrm{E}-11$ & $\mathrm{~N}+\mathrm{OH}==>\mathrm{NO}+\mathrm{H}$ & Baulch et al. 1994 \\
\hline $\mathrm{R} 188$ & $1.66 \mathrm{E}-10$ & $\mathrm{~N}+\mathrm{CH}==>\mathrm{CN}+\mathrm{H}$ & Brownsword et al. 1996 \\
\hline R189 & $1.00 \mathrm{E}-05$ & $\mathrm{~N}+\mathrm{CH} 3==>\mathrm{H} 2 \mathrm{NC}+\mathrm{H}$ & Cimas et al. 2006 \\
\hline R190 & $1.00 \mathrm{E}-36$ & $\mathrm{~N}+\mathrm{H} 2+\mathrm{A}==>\mathrm{NH} 2+\mathrm{A}$ & Petrishchev et al. 1981 \\
\hline R191 & $2.69 \mathrm{E}-34$ & $\mathrm{~N}+\mathrm{CH} 4+\mathrm{A}==>\mathrm{CH} 3 \mathrm{NH}+\mathrm{A}$ & Aleksandrov et al. 1989 \\
\hline R192 & $2.51 \mathrm{E}-14$ & $\mathrm{~N}+\mathrm{CH} 4==>\mathrm{HCN}+\mathrm{H} 2+\mathrm{H}$ & Takahashi 1972 \\
\hline R193 & $7.47 \mathrm{E}-11$ & $\mathrm{NH} 2+\mathrm{O}==>\mathrm{H}+\mathrm{HNO}$ & Cohen et al. 1991 \\
\hline R194 & $1.16 \mathrm{E}-11$ & $\mathrm{NH} 2+\mathrm{O}==>\mathrm{OH}+\mathrm{NH}$ & Cohen et al. 1991 \\
\hline R195 & $8.30 \mathrm{E}-12$ & $\mathrm{NH} 2+\mathrm{O}==>\mathrm{H} 2+\mathrm{NO}$ & Cohen et al. 1991 \\
\hline R196 & $1.65 \mathrm{E}-14$ & $\mathrm{NH} 2+\mathrm{NH}==>\mathrm{NH} 3+\mathrm{N}$ & Klippenstein et al. 2009 \\
\hline R197 & $1.70 \mathrm{E}-10$ & $\mathrm{NH} 2+\mathrm{NH}==>\mathrm{HNNH}+\mathrm{H}$ & Klippenstein et al. 2009 \\
\hline R198 & $2.06 \mathrm{E}-15$ & $\mathrm{NH} 2+\mathrm{NH} 2==>\mathrm{NH} 3+\mathrm{NH}$ & Klippenstein et al. 2009 \\
\hline R199 & $1.42 \mathrm{E}-29$ & $\mathrm{HN} 2+\mathrm{H}+\mathrm{A}==>\mathrm{NH} 3+\mathrm{A}$ & Altinay et al. 2012 \\
\hline
\end{tabular}




\begin{tabular}{|c|c|c|c|}
\hline R200 & $3.59 \mathrm{E}-12$ & $\mathrm{HNO}+\mathrm{NH} 2==>\mathrm{NH} 3+\mathrm{NO}$ & Xu et al. 2009 \\
\hline R201 & $2.38 \mathrm{E}-14$ & $\mathrm{HNO}+\mathrm{NH} 2==>\mathrm{H}+\mathrm{NH} 2 \mathrm{NO}$ & Xu et al. 2009 \\
\hline R202 & $3.84 \mathrm{E}-17$ & $\mathrm{HNO}+\mathrm{NH} 2==>\mathrm{NH} 2 \mathrm{NHO}$ & Xu et al. 2009 \\
\hline R203 & $4.54 \mathrm{E}-18$ & $\mathrm{NH} 2+\mathrm{H} 2==>\mathrm{NH} 3+\mathrm{H}$ & Mebel et al. 1999 \\
\hline R204 & $1.24 \mathrm{E}-11$ & $\mathrm{NH} 2+\mathrm{NO}==>\mathrm{N} 2+\mathrm{H} 2 \mathrm{O}$ & Park et al. 1999 \\
\hline R205 & $1.37 \mathrm{E}-12$ & $\mathrm{NH} 2+\mathrm{NO}==>\mathrm{OH}+\mathrm{HNN}$ & Park et al. 1999 \\
\hline R206 & $1.72 \mathrm{E}-15$ & $\mathrm{NH} 2+\mathrm{NH} 2 \mathrm{OH}==>\mathrm{NH} 3+\mathrm{NHOH}$ & Klippenstein et al. 2009 \\
\hline R207 & $2.55 \mathrm{E}-14$ & $\mathrm{NH} 2+\mathrm{NH} 2 \mathrm{OH}==>\mathrm{NH} 3+\mathrm{NH} 2 \mathrm{O}$ & Klippenstein et al. 2009 \\
\hline R208 & $1.10 \mathrm{E}-21$ & $\mathrm{NH} 2+\mathrm{H} 2 \mathrm{O}==>\mathrm{OH}+\mathrm{NH} 3$ & Cohen et al. 1991 \\
\hline R209 & $3.19 \mathrm{E}-12$ & $\mathrm{NH} 2+\mathrm{HNNH}==>\mathrm{NH} 3+\mathrm{HNN}$ & Linder et al. 1996 \\
\hline $\mathrm{R} 210$ & $3.93 \mathrm{E}-24$ & $\mathrm{NH} 2+\mathrm{OH}==>\mathrm{H}+\mathrm{NH} 2 \mathrm{O}$ & $\begin{array}{l}\text { Mousavipour et al. } \\
2009\end{array}$ \\
\hline $\mathrm{R} 211$ & $3.92 \mathrm{E}-13$ & $\mathrm{NH} 2+\mathrm{OH}==>\mathrm{H} 2 \mathrm{O}+\mathrm{NH}$ & $\begin{array}{l}\text { Mousavipour et al. } \\
2009\end{array}$ \\
\hline $\mathrm{R} 212$ & $2.21 \mathrm{E}-33$ & $\mathrm{NH} 2+\mathrm{OH}==>\mathrm{H} 2+\mathrm{HNO}$ & $\begin{array}{l}\text { Mousavipour et al. } \\
2009\end{array}$ \\
\hline R213 & $1.32 \mathrm{E}-36$ & $\mathrm{NH} 2+\mathrm{OH}==>\mathrm{H} 2+\mathrm{NOH}$ & $\begin{array}{l}\text { Mousavipour et al. } \\
2009\end{array}$ \\
\hline $\mathrm{R} 214$ & $8.01 \mathrm{E}-14$ & $\mathrm{NH} 2+\mathrm{OH}==>\mathrm{NH} 3+\mathrm{O}$ & $\begin{array}{l}\text { Mousavipour et al. } \\
2009\end{array}$ \\
\hline $\mathrm{R} 215$ & $3.93 \mathrm{E}-24$ & $\mathrm{NH} 2+\mathrm{OH}==>\mathrm{H}+\mathrm{NH} 2 \mathrm{O}$ & $\begin{array}{l}\text { Mousavipour et al. } \\
2009\end{array}$ \\
\hline $\mathrm{R} 216$ & $1.75 \mathrm{E}-27$ & $\mathrm{CH} 3+\mathrm{NH} 2+\mathrm{A}==>\mathrm{CH} 3 \mathrm{NH} 2+\mathrm{A}$ & Jodkowski et al. 1995 \\
\hline $\mathrm{R} 217$ & $8.40 \mathrm{E}-17$ & $\mathrm{CH} 3+\mathrm{NH} 2==>\mathrm{CH} 4+\mathrm{NH}$ & Xu et al. 1999 \\
\hline $\mathrm{R} 218$ & $8.63 \mathrm{E}-19$ & $\mathrm{C} 2 \mathrm{H} 5+\mathrm{NH} 2==>\mathrm{C} 2 \mathrm{H} 6+\mathrm{NH}$ & Xu et al. 1999 \\
\hline $\mathrm{R} 219$ & $3.98 \mathrm{E}-21$ & $\mathrm{CH} 4+\mathrm{NH} 2==>\mathrm{CH} 3+\mathrm{NH} 3$ & Song et al. 2003 \\
\hline R220 & $3.51 \mathrm{E}-16$ & $\mathrm{HO} 2+\mathrm{NH} 2==>\mathrm{H} 2 \mathrm{O}+\mathrm{NOH}$ & Sumathi et al. 1996 \\
\hline R221 & $2.50 \mathrm{E}-16$ & $\mathrm{HO} 2+\mathrm{NH} 2==>\mathrm{H} 2 \mathrm{O}+\mathrm{HNO}$ & Sumathi et al. 1998 \\
\hline $\mathrm{R} 222$ & $6.33 \mathrm{E}-18$ & $\mathrm{HO} 2+\mathrm{NH} 2==>\mathrm{NH} 3+\mathrm{O} 2$ & Sumathi et al. 1996 \\
\hline $\mathrm{R} 223$ & $3.19 \mathrm{E}-11$ & $\mathrm{HO} 2+\mathrm{NH} 2==>\mathrm{OH}+\mathrm{NH} 2 \mathrm{O}$ & Sumathi et al. 1996 \\
\hline $\mathrm{R} 224$ & $5.25 \mathrm{E}-17$ & $\mathrm{NH} 2+\mathrm{CH} 2 \mathrm{O}==>\mathrm{NH} 3+\mathrm{HCO}$ & Li et al. 2002 \\
\hline
\end{tabular}




\begin{tabular}{|c|c|c|c|}
\hline $\mathrm{R} 225$ & $5.85 \mathrm{E}-18$ & $\mathrm{HCN}+\mathrm{O}==>\mathrm{CO}+\mathrm{NH}$ & Perry et al. 1985 \\
\hline R226 & 4.99E-18 & $\mathrm{HCN}+\mathrm{O}==>\mathrm{H}+\mathrm{NCO}$ & Perry et al. 1985 \\
\hline R227 & $1.70 \mathrm{E}-30$ & $\mathrm{HCN}+\mathrm{O}==>\mathrm{CN}+\mathrm{OH}$ & Perry et al. 1985 \\
\hline R228 & 4.72E-28 & $\mathrm{HCN}+\mathrm{H}==>\mathrm{CN}+\mathrm{H} 2$ & Tsang et al. 1991 \\
\hline R229 & $4.28 \mathrm{E}-19$ & $\mathrm{HCN}+\mathrm{OH}==>\mathrm{CN}+\mathrm{H} 2 \mathrm{O}$ & Tsang et al. 1991 \\
\hline R230 & $3.18 \mathrm{E}-22$ & $\mathrm{HCN}+\mathrm{OH}==>\mathrm{CO}+\mathrm{NH} 2$ & Miller et al. 1988 \\
\hline R231 & $1.23 \mathrm{E}-36$ & $\mathrm{HCN}+\mathrm{HCO}==>\mathrm{CH} 2 \mathrm{O}+\mathrm{CN}$ & Feng et al. 1997 \\
\hline R232 & $1.40 \mathrm{E}-10$ & $\mathrm{CN}+\mathrm{O}==>\mathrm{CO}+\mathrm{N}$ & Andersson et al. 2003 \\
\hline R233 & $1.66 \mathrm{E}-12$ & $\mathrm{HNNO}+\mathrm{OH}==>\mathrm{NO}+\mathrm{NHOH}$ & Lin et al. 1992 \\
\hline R234 & $2.90 \mathrm{E}-14$ & $\mathrm{HNNO}+\mathrm{NO}==>\mathrm{N} 2+\mathrm{HNO} 2$ & Lin et al. 1992 \\
\hline $\mathrm{R} 235$ & $2.16 \mathrm{E}-12$ & $\mathrm{HNNO}+\mathrm{NO}==>\mathrm{NO} 2+\mathrm{HNN}$ & Lin et al. 1992 \\
\hline $\mathrm{R} 236$ & $3.57 \mathrm{E}-14$ & $\mathrm{HNO}+\mathrm{NO} 2==>\mathrm{HNO} 2+\mathrm{NO}$ & Tsang et al. 1991 \\
\hline R237 & $1.04 \mathrm{E}-11$ & $\mathrm{HNO}+\mathrm{CH} 3==>\mathrm{CH} 4+\mathrm{NO}$ & Choi et al. 2005 \\
\hline R238 & $3.20 \mathrm{E}-30$ & $\mathrm{NO} 2+\mathrm{OH}+\mathrm{A}==>\mathrm{HNO} 3+\mathrm{A}$ & Troe 2012 \\
\hline R239 & $3.63 \mathrm{E}-13$ & $\mathrm{HNO} 3+\mathrm{NH} 2==>\mathrm{NH} 3+\mathrm{NO} 3$ & Xu et al. 2010 \\
\hline $\mathrm{R} 240$ & $3.20 \mathrm{E}-30$ & $\mathrm{NO} 2+\mathrm{OH}+\mathrm{A}==>\mathrm{HNO} 3+\mathrm{A}$ & Troe 2012 \\
\hline $\mathrm{R} 241$ & $4.09 \mathrm{E}-16$ & $\mathrm{NO} 2+\mathrm{OH}==>\mathrm{HO} 2+\mathrm{NO}$ & Tsang et al. 1991 \\
\hline $\mathrm{R} 242$ & $1.45 \mathrm{E}-10$ & $\mathrm{NO} 2+\mathrm{CH}==>\mathrm{HCO}+\mathrm{NO}$ & Tao et al. 2001 \\
\hline $\mathrm{R} 243$ & $1.70 \mathrm{E}-11$ & $\mathrm{NO} 3+\mathrm{O}==>\mathrm{NO} 2+\mathrm{O} 2$ & Atkinson et al. 2004 \\
\hline R244 & $2.59 \mathrm{E}-11$ & $\mathrm{NO} 3+\mathrm{NO}==>\mathrm{NO} 2+\mathrm{NO} 2$ & Atkinson et al. 2004 \\
\hline $\mathrm{R} 245$ & $2.00 \mathrm{E}-11$ & $\mathrm{NO} 3+\mathrm{OH}==>\mathrm{NO} 2+\mathrm{HO} 2$ & Atkinson et al. 2004 \\
\hline R246 & $2.51 \mathrm{E}-10$ & $\mathrm{NH} 3+\mathrm{Od}==>\mathrm{OH}+\mathrm{NH} 2$ & DeMore et al. 1997 \\
\hline $\mathrm{R} 247$ & $1.18 \mathrm{E}-24$ & $\mathrm{NH} 3+\mathrm{CH} 3==>\mathrm{CH} 4+\mathrm{NH} 2$ & Yu et al. 1998 \\
\hline $\mathrm{R} 248$ & $1.58 \mathrm{E}-31$ & $\mathrm{~N} 2+\mathrm{CH}==>\mathrm{CHN} 2$ & Le Picard et al. 1998 \\
\hline R249 & $1.58 \mathrm{E}-31$ & $\mathrm{~N} 2+\mathrm{CH}==>\mathrm{CHN} 2$ & Le Picard et al. 1998 \\
\hline $\mathrm{R} 250$ & $3.32 \mathrm{E}-11$ & $\mathrm{HO} 2+\mathrm{NCO}==>\mathrm{HNCO}+\mathrm{O} 2$ & He et al. 1993 \\
\hline $\mathrm{R} 251$ & $5.70 \mathrm{E}-11$ & $\mathrm{HO} 2+\mathrm{O}==>\mathrm{OH}+\mathrm{O} 2$ & Atkinson et al. 2004 \\
\hline R252 & $5.70 \mathrm{E}-11$ & $\mathrm{HO} 2+\mathrm{O}==>\mathrm{OH}+\mathrm{O} 2$ & Atkinson et al. 2004 \\
\hline $\mathrm{R} 253$ & $5.33 \mathrm{E}-80$ & $\mathrm{HO} 2+\mathrm{NO}==>\mathrm{HOONO}$ & Zhu et al. 2003 \\
\hline $\mathrm{R} 254$ & $1.11 \mathrm{E}-14$ & $\mathrm{HO} 2+\mathrm{NO}==>\mathrm{O} 2+\mathrm{HNO}$ & Howard 1979 \\
\hline
\end{tabular}




\begin{tabular}{|c|c|c|c|}
\hline $\mathrm{R} 255$ & $8.86 \mathrm{E}-12$ & $\mathrm{HO} 2+\mathrm{NO}==>\mathrm{OH}+\mathrm{NO} 2$ & Atkinson et al.2004 \\
\hline R256 & $5.87 \mathrm{E}-35$ & $\mathrm{HO} 2+\mathrm{H} 2 \mathrm{O}==>\mathrm{OH}+\mathrm{H} 2 \mathrm{O} 2$ & Lloyd 1974 \\
\hline $\mathrm{R} 257$ & $3.80 \mathrm{E}-11$ & $\mathrm{HNO}+\mathrm{O}==>\mathrm{OH}+\mathrm{NO}$ & Inomata 1999 \\
\hline $\mathrm{R} 258$ & $3.02 \mathrm{E}-19$ & $\mathrm{HNO}+\mathrm{HNO}==>\mathrm{NO}+\mathrm{NHOH}$ & Lin et al. 1992 \\
\hline R259 & $8.48 \mathrm{E}-18$ & $\mathrm{HNO}+\mathrm{HNO}==>\mathrm{N} 2 \mathrm{O}+\mathrm{H} 2 \mathrm{O}$ & Lin et al. 1992 \\
\hline $\mathrm{R} 260$ & $1.12 \mathrm{E}-14$ & $\mathrm{HNO}+\mathrm{NHOH}==>\mathrm{NH} 2 \mathrm{OH}+\mathrm{NO}$ & Lin et al. 1992 \\
\hline R261 & $2.14 \mathrm{E}-22$ & $\mathrm{HNO}+\mathrm{H}==>\mathrm{NH}+\mathrm{OH}$ & Cohen et al. 1991 \\
\hline R262 & $5.68 \mathrm{E}-12$ & $\mathrm{HNO}+\mathrm{H}==>\mathrm{H} 2+\mathrm{NO}$ & Tsang et al. 1991 \\
\hline R263 & $1.51 \mathrm{E}-11$ & $\mathrm{HNO}+\mathrm{OH}==>\mathrm{H} 2 \mathrm{O}+\mathrm{NO}$ & Tsang et al. 1991 \\
\hline R264 & $3.81 \mathrm{E}-19$ & $\mathrm{HNO}+\mathrm{CH} 3==>\mathrm{CH} 3 \mathrm{NO}+\mathrm{H}$ & Choi et al. 2005 \\
\hline R265 & 4.49E-29 & $\mathrm{HNO}+\mathrm{HCO}==>\mathrm{CO}+\mathrm{NHOH}$ & Xu et al. 2004 \\
\hline R266 & 4.47E-24 & $\mathrm{HNO}+\mathrm{HCO}==>\mathrm{CO}+\mathrm{NH} 2 \mathrm{O}$ & Xu et al. 2004 \\
\hline $\mathrm{R} 267$ & $8.19 \mathrm{E}-25$ & $\mathrm{HNO}+\mathrm{HCO}==>\mathrm{CH} 2 \mathrm{O}+\mathrm{NO}$ & Xu et al. 2004 \\
\hline R268 & $5.25 \mathrm{E}-11$ & $\mathrm{HNO}+\mathrm{CH} 3 \mathrm{O}==>\mathrm{CH} 3 \mathrm{OH}+\mathrm{NO}$ & He et al. 1988 \\
\hline R269 & $7.49 \mathrm{E}-14$ & $\mathrm{NH} 2 \mathrm{OH}+\mathrm{OH}==>\mathrm{H} 2 \mathrm{O}+\mathrm{NHOH}$ & Klippenstein et al. 2009 \\
\hline $\mathrm{R} 270$ & $4.66 \mathrm{E}-15$ & $\mathrm{NH} 2 \mathrm{OH}+\mathrm{OH}==>\mathrm{H} 2 \mathrm{O}+\mathrm{NH} 2 \mathrm{O}$ & Klippenstein et al. 2009 \\
\hline R271 & $1.66 \mathrm{E}-12$ & $\mathrm{NHOH}+\mathrm{H}==>\mathrm{H} 2+\mathrm{HNO}$ & Lin et al. 1992 \\
\hline $\mathrm{R} 272$ & $1.66 \mathrm{E}-12$ & $\mathrm{NHOH}+\mathrm{OH}==>\mathrm{H} 2 \mathrm{O}+\mathrm{HNO}$ & Lin et al. 1992 \\
\hline $\mathrm{R} 273$ & $1.52 \mathrm{E}-05$ & $\mathrm{NHOH}+\mathrm{HCO}==>\mathrm{CO}+\mathrm{NH} 2 \mathrm{OH}$ & Xu et al. 2004 \\
\hline $\mathrm{R} 274$ & $1.85 \mathrm{E}-08$ & $\mathrm{NHOH}+\mathrm{HCO}==>\mathrm{CO}+\mathrm{H} 2+\mathrm{HNO}$ & Xu et al. 2004 \\
\hline $\mathrm{R} 275$ & $1.64 \mathrm{E}-05$ & $\mathrm{NHOH}+\mathrm{HCO}==>\mathrm{CH} 2 \mathrm{O}+\mathrm{HNO}$ & $\mathrm{Xu}$ et al. 2005 \\
\hline $\mathrm{R} 276$ & $1.99 \mathrm{E}-11$ & $\mathrm{HNO} 2+\mathrm{O}==>\mathrm{OH}+\mathrm{NO} 2$ & Tsang et al. 1991 \\
\hline R277 & $6.43 \mathrm{E}-13$ & $\mathrm{HNO} 2+\mathrm{H}==>\mathrm{H} 2 \mathrm{O}+\mathrm{NO}$ & Hsu et al. 1997 \\
\hline $\mathrm{R} 278$ & $1.26 \mathrm{E}-11$ & $\mathrm{HNO} 2+\mathrm{H}==>\mathrm{OH}+\mathrm{HNO}$ & Hsu et al. 1997 \\
\hline R279 & $2.27 \mathrm{E}-12$ & $\mathrm{HNO} 2+\mathrm{H}==>\mathrm{H} 2+\mathrm{NO} 2$ & Hsu et al. 1997 \\
\hline $\mathrm{R} 280$ & $6.00 \mathrm{E}-12$ & $\mathrm{HNO} 2+\mathrm{OH}==>\mathrm{H} 2 \mathrm{O}+\mathrm{NO} 2$ & Atkinson et al. 2004 \\
\hline $\mathrm{R} 281$ & $3.23 \mathrm{E}-32$ & $\mathrm{HNO} 2+\mathrm{HCO}==>\mathrm{CO}+\mathrm{H} 2 \mathrm{O}+\mathrm{NO}$ & Xu et al. 2004 \\
\hline R282 & $1.43 \mathrm{E}-51$ & $\mathrm{HNO} 2+\mathrm{HCO}==>\mathrm{CH} 2 \mathrm{O}+\mathrm{NO} 2$ & Xu et al. 2004 \\
\hline $\mathrm{R} 283$ & $3.63 \mathrm{E}-13$ & $\mathrm{HNO} 3+\mathrm{NH} 2==>\mathrm{NH} 3+\mathrm{NO} 3$ & Xu et al. 2010 \\
\hline $\mathrm{R} 284$ & $3.76 \mathrm{E}-19$ & $\mathrm{HNO} 3+\mathrm{H}==>\mathrm{H} 2 \mathrm{O}+\mathrm{NO} 2$ & Boughton et al. 1997 \\
\hline
\end{tabular}




\begin{tabular}{|l|l|l|l|}
\hline R285 & $6.41 \mathrm{E}-24$ & $\mathrm{HNO} 3+\mathrm{H}==>\mathrm{H} 2+\mathrm{NO} 3$ & Boughton et al. 1997 \\
\hline R286 & $1.50 \mathrm{E}-20$ & $\mathrm{HNO} 3+\mathrm{NO}==\mathrm{HNO} 2+\mathrm{NO} 2$ & Kaiser et al. 1977 \\
\hline R287 & $4.18 \mathrm{E}-11$ & $\mathrm{CN}+\mathrm{NCO}==>\mathrm{CO}+\mathrm{NCN}$ & Tzeng et al. 2009 \\
\hline R288 & $1.69 \mathrm{E}-11$ & $\mathrm{CN}+\mathrm{O}==>\mathrm{CO}+\mathrm{N}$ & Baulch et al. 1992 \\
\hline R289 & $8.05 \mathrm{E}-11$ & $\mathrm{CN}+\mathrm{NO} 2==>\mathrm{NO}+\mathrm{NCO}$ & Park et al. 1993 \\
\hline R290 & $7.11 \mathrm{E}-12$ & $\mathrm{CN}+\mathrm{NO} 2==>\mathrm{CO}+\mathrm{N} 2 \mathrm{O}$ & Park et al. 1993 \\
\hline R291 & $5.20 \mathrm{E}-12$ & $\mathrm{CN}+\mathrm{NO} 2==\mathrm{CO} 2+\mathrm{N} 2$ & Park et al. 1993 \\
\hline R292 & $1.60 \mathrm{E}-13$ & $\mathrm{CN}+\mathrm{NO}==>\mathrm{CO}+\mathrm{N} 2$ & Li et al. 1985 \\
\hline R293 & $2.42 \mathrm{E}-11$ & $\mathrm{CN}+\mathrm{O} 2==>\mathrm{O}+\mathrm{NCO}$ & Baulch et al. 1994 \\
\hline R294 & $1.66 \mathrm{E}-16$ & $\mathrm{CN}+\mathrm{NH} 3==>\mathrm{HCN}+\mathrm{NH} 2$ & Baulch et al. 1981 \\
\hline R295 & $2.47 \mathrm{E}-14$ & $\mathrm{CN}+\mathrm{H} 2==>\mathrm{HCN}+\mathrm{H}$ & Choi et al. 2004 \\
\hline R296 & $8.58 \mathrm{E}-13$ & $\mathrm{CN}+\mathrm{CH} 4==>\mathrm{HCN}+\mathrm{CH} 3$ & Baulch et al. 1994 \\
\hline R297 & $1.69 \mathrm{E}-13$ & $\mathrm{CN}+\mathrm{CH} 2 \mathrm{O}==>\mathrm{CN}+\mathrm{HCO}$ & Feng et al. 1997 \\
\hline
\end{tabular}

